\title{
COUSIN MARRIAGE AND THE EVOLUTION OF THE BREEDING SYSTEM IN MAN
}

\author{
C. D. DARLINGTON \\ Botany School, Oxford
}

Received I5.viii.59

\section{ANALYTICAL AND INTEGRAL GENETICS}

THE success of the Mendelian method in experimental breeding made it, sixty years ago, the natural model for understanding human heredity. The success of the model in interpreting the clinical entities which dominate medical training and in classifying them as Mendelian characters in due course reinforced this initial advantage. Lately, however, certain limitations of the method and the model have become evident. Man exists in natural outbreeding populations. His variation in these populations can only partly be reduced to terms of single gene differences. Faced with this discovery some students have inferred that such human variation cannot be genetically analysed or: indeed analysed at all. Since, however, the strict Mendelian situation can hardly be expected to exist in outbreeding populations, this conclusion is unjustified.

To put the matter in another way: the genotype is, we may still agree, the sum of the genes. But a difference between genotypes is not just the sum of the differences between their genes. Indeed no one imagines that the genotype can be taken apart into polygenes, major genes, super-genes, with position effects, structural arrangements and so on. There is, therefore, one sense in which analysis in terms of genes or ultimately nucleotides is a suitable goal. But there is another sense in which it fails to tell us what we want to know, a sense in which an integral treatment is suitable and necessary.

This contrast was forced on me by the study of whole segments, whole chromosomes and whole nuclei in cells, in natural populations, and in hybrids, as I have described elsewhere (1956, I957, I958). Mather (I955) has seen the same problem in terms of quantitative variation and the breeding system, and especially by the exposure of the correlated response to selection. Dobzhansky and his colleagues have discovered it from the experimental treatment and chromosome study of natural populations, where they have recognised both the co-adaptation of segments and the integration of the genotype (Dobzhansky, 1950; Vetukhiv, I954; Wallace, 1957a, $b$ ). These different kinds of approach lead to different statements of contrast and conflict. Each no doubt has its own physiological scope and validity.

The difference between these analytical and integral extremes, the difference between the single gene of Mendelian analysis and the whole genotype considered by Galton and Johannsen is almost of the order of 
the difference between chemistry and biology. Both, like chemistry and biology, have their validity. But we cannot use one where the other is needed. Yet where man is concerned this is just what we see continually attempted. Analytical principles involving frequencies of analytical units, whether "genes" or "mutations", are directly applied to the non-analysable situation, for example the situation of radiation damage.

Now, in human heredity and variation certain properties most need integral treatment and suffer most from analytical treatment. These happen to be the properties of greatest importance for our survival and our evolution. They are the properties of temperament, of intelligence, of instinct, of their combination in behaviour, of viability and fertility, of resistance or susceptibility to infectious disease. These are integral properties. They depend on interactions of a great assembly of independently varying units. These interactions are on a scale which is not beyond conception, but it is beyond formal description or practical analysis.

TABLE $\mathrm{I}$

Relation between fertility of mother and daughter in the British Peerage (after Fisher, 1930, data of Pearson and Lee, 1899)

No. of children born to mother

Average to daughter

$\begin{array}{lllr}1 & 5 & \text { 11 } & >11 \\ 3 \cdot 0 & 4 \cdot 0 & 5.1 & 6 \cdot 4\end{array}$

This genetical principle is an expression of physiological and developmental situations. Take the basic evolutionary property of leaving descendants, a property which I am going to call fertility. This property depends on a sequence of elements: a desire for sexual intercourse, an ability to beget and bear offspring, a viability of embryos and offspring.* To these elements the development of birth control requires us to add one more, the desire to have offspring. These several elements overlap. The distinction between survival to birth and survival after birth is partly arbitrary. So is the distinction between not marrying and marrying but not having children after marriage. Thus we are bound to profit from considering the total reproductive result. Though the parts are arbitrary the whole is a reality: it is the great reality in life. In this we have the example of Galton before us. We also have Galton's and Pearson's methods of correlation in numbers of progeny between parents and offspring (table I).

The observations of Galton and Pearson could be repeated with profit under the changed reproductive conditions of the present day. It would also be of great value to confirm the remarkable change in sex ratio shown by Galton's data (I869). Meanwhile we may note that these correlations must depend on two components whose relative value we can only surmise, namely heritability which has to be a

* This is the element which has been separately examined by most investigators who have found a depressing effect of inbreeding, e.g. Bemiss, 1858 ; Darwin, 1875 ; Steven son, 1956 ; Morton et al., 1956 ; Schull, $195^{8}$; Slatis, 1958. 
primary agent, and assortative mating which will be a secondary agent. We know, following Pearson and Lee (I903), that assortative mating occurs in respect of every character in which the mates can be separately classified. Fertility is the one character in which they cannot be separated but it is one in which we have as much reason as in any other to expect assortative mating.

The method of attacking this problem of fertility that I wish to use, while omitting one of the two elements of the Mendelian experiment, the differential unit character, exploits the other, the change in the breeding system. The theory of this method has been discussed by Mather (1955) and the practice by myself (1955). Its technique in the human situation has a special character. Mendel's sequence: inbreeding, outbreeding, inbreeding, occurs in human populations only in special circumstances such as we find in Pitcairn Island and Tristan da Cunha. But we find the alternative, outbreeding, inbreeding, outbreeding in our own society if we follow the results of cousin marriage. For this we need to know two or three generations before the marriage and two or three generations after. We need to know something about the breeding system in the whole group. Is this possible?

\section{EUROPEAN BREEDING SYSTEMS}

The integral study of viability, fertility or intelligence by change of the breeding system requires that we shall know what the system is that is being changed. The human breeding system in class-differentiated human societies may be roughly defined in terms of two limits: (i) the limits to outbreeding and (ii) the limits to inbreeding.

(i) The limits to outbreeding are set by space, work, language or dialect, religion and economic or social status. All these are the environmental components in a reaction favouring kinship, or relationship of descent, among mates. The genetic component of this reaction may be described as the tendency to assortative mating. The two components reinforce the tendency to inbreed. For the phenotypic likeness of mates as expressed in assortative mating, and their relationship of descent, are two means of measuring inbreeding. To be sure they are both uncertain and for quite different reasons. Similar appearance may be due to similar genetic structure or not. Relationship of descent also may imply similarity of genetic structure or not. Nevertheless assortative mating and kinship will reinforce rather than counteract one another.

The environmental components themselves interact in complex ways. Thus social status divides the whole population into social classes. Space is a stronger barrier at the lower social levels. So also is religion. The earlier Christian community of Northern Europe was split by the Reformation into numerous non-interbreeding sects but at the Royal level these divisions are only partly effective: Protestant females may marry Catholic males. Only one of the Protestant 
sects exist as a small minority at higher social and intellectual levels, that is the Quakers. The Jewish community at its Western edge is a larger breeding group but it exists at all social levels which divides it further. Other very small breeding groups have arisen from economic and political grounds, the merchant princes of Chios, Venice and Amsterdam, and elsewhere. By contrast with these the prosperous middle class in Britain following the industrial revolution must have been extremely outbred. Even here foci of inbreeding have quickly arisen, for example in connection with universities.

(ii) With regard to the limits to inbreeding all human societies make rules.* In Europe these limits are easily defined. The Catholic Church early set its face against inbreeding as permitted by Roman custom or Jewish law. This policy arose we may say from a habit of making rules for conduct. The reasons given by Gregory the Great in his letter to Augustine (cit. Bede) that cousin marriages give no offspring are scarcely to be taken seriously. Some of the rules have always been flagrantly and repeatedly broken by dispensation. Thus first-cousin marriages have been widespread in Catholic communities up to the present day. They are most frequent in the narrowing Royal caste where also uncle-niece marriages continued up to 1850 .

The Reformation affected the inbreeding as well as the outbreeding limits. The Protestant churches, except the Swedish (Alström, I958), gave up the nominal ban on cousin marriages but began to enforce a ban on uncle-niece marriages. Amongst Jewish minorities the pressure in favour of close inbreeding led to the highest frequency of uncle-niece marriage.

On account of these variations different communities in Europe provide us with all the contrasts we need: 16 per cent. of first-cousin and 3 per cent. of second-cousin marriages among Jews in Hohenzollern villages, the reverse among Catholics in a Swiss village (Neel et al., I949; Kilpatrick et al., I955). Even so, as we shall see, such statistics of cousin marriage give us very little idea of the real contrast. This arises from the consideration of still more specialised groups, very small sects such as the Mennonites and very small castes such as the Royal Families. With these we can discover the selective and evolutionary principles at work.

\section{METHODS OF ENQUIRY}

My object was to find out the genetic component in differences in the total reproductive potential or "fertility" in human marriages. I enquired first in the Oxford Magazine (December, 1957) for grandchildren of cousin marriages who would give me the total numbers of descendants of such marriages up to the greatgrandchildren. From this beginning I was able to elaborate the question in the

* Following Darwin's lead in the Descent of Man, the documentary evidence of the restrictions on inbreeding in civilised man was compiled by Huth (1875). Here are to be found pedigrees of the Ptolemies, Herods, Antonines, and European Royal Families, as well as an account of the vagaries of Roman and Christian doctrine on the matter. Many of the properties of the Royal caste have recently been summarised by Moncrieffe and Pottinger (1956). Compare also: Life and Letters of Charles Darwin, 3, 129. 
London Observer (January 1958) and in Messrs Sandoz's house journal Triangle (November 1958) which is addressed to the medical profession generally in the British Commonwealth and Western Europe.

The results of these enquiries were replies giving data of five kinds in increasing order of complexity :

(i) for single cousin marriages ancestral to the correspondent,

(ii) for others which were collateral or even unrelated to the correspondent,

(iii) for successive or grouped cousin marriages (including Royal marriages) often from experienced genealogists,

(iv) for " parallel sib marriages" with cousins and non-cousins,

(v) for "double test marriages" of one spouse with a cousin (or uncle) and a non-cousin.

The first class was the most important. Since it excluded marriages without grandchildren, it biased the sample in favour of fertility. But as H. G. Darwin pointed out, the numbers of marriageable cousins increase with the size of the family and exponentially with the generations. Cousin marriages are therefore inherently biased at their origin, or self-biased, in favour of high fertility. The third, fourth and fifth classes can be used in different ways to correct this situation.

The method I have developed was indicated in an earlier note (1955). It is to find out the following particulars (Abbreviations in Appendix):

(i) Dates of birth, marriage and death of the original cousins.

(ii) Total children, grandchildren or great-grandchildren born alive (c, gc, ggc in tables). Stillbirths were omitted since early data would be unreliable in this respect.

(iii) Total $\mathrm{c}$ and gc surviving to maturity (s) or between 22 and 24 years of age.

(iv) Total $\mathrm{c}$ and gc marrying $(\mathrm{m})$.

(v) Total $\mathrm{c}$ and gc marrying and with issue (wi).

These last three I speak of as the successive " tests" in the reproductive cycle.

Later and especially in the double test marriages I enquired into the occurrence of previous cousin marriages and the type of breeding group of the original cousins. Thus at least seven generations had to be considered, and along some lines in some families as many as fourteen generations have been followed.

As I had expected, but with greater detail than I had expected, a wide range of breeding systems was revealed by my correspondents. They fell into three general groups :

(i) An extreme group which were known on social, political or religious grounds, or from their own pedigrees, to have been inbred for many generations.

(ii) An intermediate group in which cousin marriage (whether in a first or more remote degree) was known among the parents or grandparents of the critical marriage spouses.

(iii) Those with no evidence of inbreeding of either of these kinds.

Clearly this division is an arbitrary and provisional one. It conceals a continuous range of variation: it emphasises, however, a genuine bimodality in the breeding system. The large outbred group must include some slightly inbred stocks. But this will merely blunt the contrast I am trying to make.

This method turns out to be even more closely than might have been expected a mirror image of the Mendelian experiment. The following table shows their relations :

$\begin{array}{cll}\text { Generations } & \text { Mendel's experiment } & \text { Cousin marriage method } \\ n & \text { inbreed } & \text { outbreed } \\ \text { one } & \text { outbreed }(\mathbf{P}) & \text { inbreed }(\mathrm{cm}) \\ n & \text { inbreed }\left(\mathrm{F}_{1}, \mathbf{F}_{2}, \text { etc. }\right) & \text { outbreed }(\mathrm{c}, \mathrm{gc}, \mathrm{ggc})\end{array}$

In addition, however, we can check the cousin marriage method by controls varying the degree and frequency of inbreeding in the prior generations. 
It will be observed that no account is taken of the possibility of unknown illegitimacy of the parents or false paternity of the offspring who are wrongly included or wrongly excluded. But it will be seen that illegitimacy, or rather mistaken assignments of paternity, can only equalise the differences between classes of matings ; it cannot enhance them. Within classes it should of course enhance variances.

It will also be observed that certain events concerned in the lives of individuals can have no genetic component capable of selection in common with genuine genetic properties. Death in war and murder are two such types of event and I have therefore noted instances of these. All other relevant events I regard as apt to be genetically significant. Such are suicide, susceptibility to infectious disease, age of marriage, divorce, and others I shall refer to which are even more obviously genetic and selectable.

\section{THE GENERAL POPULATION}

The general results shown in table 2 give us a picture of the consequences of cousin marriage with progeny in the educated class in Britain where family records have been maintained during the last two centuries. They cover the range from one to fifteen children of the first marriage. They attempt the division into inbred and outbred stocks. They exclude only marriages without offspring and certain complex families which I shall consider later in detail (tables 3, 6, 7).

The summaries of the two groups of data provide us with a number of controlled comparisons from which we may draw tentative conclusions as follows:

(i) From the same average numbers of about six children per original marriage the inbred groups produce more than twice as many ggc as the outbred groups $(28 \cdot 6$ against $\mathrm{I} 2 \cdot 8)$.

(ii) This difference is not due to a difference in the numbers of children per fertile marriage which show a similar decline in all groups from generation to generation following the national trend.

(iii) It is not due to any difference between the properties of the grandchildren of the two groups. Both of these have about $3 \mathrm{ggc}$ p. $\mathrm{m}$ (wi) and about 50 per cent. of $\mathrm{m}$ (wi) p. gc. They thus act together as a control generation.

(iv) It is due to the survival, marriage and reproductive rates of the children being depressed to 40 per cent. in the outbred groups and raised to over 6o per cent. in the inbred groups, in comparison with the following control generation.

(v) The outbred group is large enough to divide into more and less fertile sections in respect of parents $\left(9^{\cdot} / \mathrm{I}^{\circ} \mathrm{O}\right)$. We find that their fertility difference is maintained in the following $\mathrm{c}$ and gc generations.

(vi) Such a continuance over two generations results in the extreme disparity of $22 \cdot 3 / 6 \cdot 8$ in ggc per original marriage. It implies an effect of assortative mating.

At this stage we are in a position to say something further about bias. It seems that the bias towards excessive fertility in the products of cousin marriages does not affect these inferences since the inbred and outbred groups which diverge in the first generation are equalised 
TABLE 2

Descendants of marriages between first cousins

Data obtained from correspondents and historical records

Omitted are certain families in tables $5,7,8$ and 14

Arranged in chronological order within the family number classes

TABLE 2A

Families without previous evidence of inbreeding

\begin{tabular}{|c|c|c|c|c|c|c|c|c|c|c|c|}
\hline \multirow{2}{*}{ Name } & & \multirow{2}{*}{ Date } & \multicolumn{4}{|c|}{ c } & \multicolumn{4}{|c|}{ gc } & \multirow{2}{*}{$\begin{array}{c}\text { ggc } \\
\qquad \\
\text { t }\end{array}$} \\
\hline & & & $\mathrm{t}$ & $\mathbf{s}$ & $\mathrm{m}$ & wi & $t$ & $\mathbf{s}$ & $\mathrm{m}$ & wi & \\
\hline Ruskin . & . & I 8 I 8 & I & I & $I^{1}$ & 0 & $\cdots$ & $\cdots$ & $\cdots$ & $\ldots$ & $\cdots$ \\
\hline Hamilton & . & I 897 & I & I & I & $I$ & $\mathbf{I}$ & I & I & I & 4 \\
\hline Colbourne & . & I 908 & I & I & I & $\mathrm{o}$ & $\cdots$ & $\cdots$ & $\ldots$ & $\cdots$ & $\cdots$ \\
\hline Ardenne & . & c. 1870 & 2 & 2 & I & I & $\mathbf{I}$ & I & I & I & 5 \\
\hline Sartoris (I) & . & I 890 & 2 & 2 & 0 & $\cdots$ & $\cdots$ & $\cdots$ & $\cdots$ & $\cdots$ & $\cdots$ \\
\hline Sartor is (2) & . & 1897 & 2 & 2 & 0 & $\ldots$ & $\ldots$ & $\ldots$ & ... & $\cdots$ & $\cdots$ \\
\hline Davidson & - & I 874 & 3 & 2 & I & I & $\mathbf{I}$ & I & I & I & 3 \\
\hline Dennis . & - & I 885 & 3 & 3 & 3 & 3 & 4 & 4 & 4 & 4 & $\mathbf{x}+$ \\
\hline Brown . & . & c. I $8 \mathrm{IO}$ & 4 & 3 & 3 & 2 & 19 & I 2 & IO & 9 & $3^{\circ}$ \\
\hline Sutton . & - & I $84^{8}$ & 4 & 4 & 3 & 2 & 3 & 2 & I & 0 & .. \\
\hline Simon . & . & I 868 & 4 & 4 & 3 & 3 & 4 & 4 & 2 & 2 & 3 \\
\hline Ware & - & I 892 & 4 & 3 & 3 & 2 & 3 & 3 & 2 & 2 & $5+$ \\
\hline Hart . & . & c. I 8 I 3 & 5 & 5 & 5 & 2 & 6 & 6 & 4 & 4 & 7 \\
\hline Candy ${ }^{2}$. & - & c. 1825 & 5 & 3 & 2 & $\mathrm{I}^{3}$ & 19 & I 3 & I I & 8 & 28 \\
\hline Bradish . & . & I 840 & 5 & 5 & 3 & I & 9 & 9 & 2 & I & 2 \\
\hline Wade & - & I 858 & 5 & 5 & $4^{4}$ & 2 & 6 & 5 & 5 & 4 & 5 \\
\hline Braun . & . & I 860 & 5 & 2 & 2 & 2 & 6 & 6 & 4 & 3 & 5 \\
\hline Cooper . & . & I 872 & 5 & 4 & 4 & 4 & 6 & 5 & 5 & 5 & 9 \\
\hline King . & . & I8I 3 & & 5 & 3 & I & 13 & IO & 8 & 5 & 13 \\
\hline Freestone & • & c. 1820 & $6+5$ & 6 & $3^{6}$ & 2 & 12 & 12 & 7 & 6 & 13 \\
\hline Sillar . & - & I 862 & 6 & 3 & 2 & 2 & 5 & 5 & 4 & 3 & 9 \\
\hline Hick . & - & I 882 & 6 & 5 & 2 & $2^{7}$ & 6 & 6 & 6 & 6 & $8+$ \\
\hline Gwynn . & • & I 889 & 6 & 4 & 2 & 0 & $\cdots$ & $\cdots$ & $\cdots$ & $\cdots$ & $\cdots$ \\
\hline Berry . & . & c. I 895 & $6^{8}$ & 3 & 3 & I & 2 & 2 & 2 & 2 & $4+$ \\
\hline Boswell ${ }^{\circ}$ & • & I 769 & 7 & 5 & 2 & 2 & 9 & 6 & 5 & 4 & $14+10$ \\
\hline $\begin{array}{l}\text { Thornton- } \\
\text { Duesbury }\end{array}$ & & 1865 & 7 & 7 & 2 & I & 2 & 2 & o & $\cdots$ & $\cdots$ \\
\hline Folwell & - & I 8go & 7 & 2 & 2 & 2 & 3 & 2 & 2 & 2 & $5+$ \\
\hline Macleod 11 & •. & c. I 855 & 8 & 5 & 5 & 4 & Io & 812 & 5 & 5 & II \\
\hline Whone . & . & c. I 900 & 8 & 4 & 4 & 4 & 12 & 12 & 8 & $4+$ & rot \\
\hline Watson & - & c. I 815 & 9 & $6^{13}$ & 4 & 3 & 9 & 8 & 5 & 5 & $x \mathbf{x}+$ \\
\hline M'Conaghy & - & I 86 I & 9 & 7 & 3 & 2 & 14 & 9 & 9 & 9 & 24 \\
\hline Abraham & - & c. $1855^{14}$ & 10 & 8 & 6 & 6 & $2 I^{15}$ & I 4 & I 3 & I I & 15 \\
\hline Scott & . & c. 1856 & I I & I I & 4 & 4 & Io & 5 & 4 & 4 & 15 \\
\hline Kindersley ${ }^{18}$ & . & I 857 & I I & 10 & 7 & 5 & $\mathbf{I}_{3}$ & 12 & $9+$ & 7 & I8 \\
\hline Callender ${ }^{17}$ & . & 1858 & I I & 10 & 6 & 6 & 21 & I 6 & 13 & IO & 33 \\
\hline " Reid" & - & I 853 & 12 & 9 & 4 & 3 & Io & 8 & $7^{18}$ & 5 & 9 \\
\hline Pittmann & • & I 826 & 13 & $10^{18}$ & 3 & 3 & 15 & I 4 & I I & 10 & 23 \\
\hline Trench ${ }^{20}$ & - & I 832 & 14 & IO & 8 & 6 & 35 & $3 I$ & 23 & I 5 & $35+$ \\
\hline Walker $^{21}$ & - & 1867 & 15 & I 3 & I I & I O & $3^{2}$ & 30 & 26 & $2 \mathrm{I}$ & 54 \\
\hline
\end{tabular}

1 Marriage not consummated

3 Rev. Herbert Candy

5 Possible infant deaths not recorded

7 Another $\mathrm{cm}$

James Boswell (1 740-95)

11 Died at 38

13 Two unmd. born blind

15 Three killed, 4 others died

17 See table i 5

12 One emigrated, no record ; one suicide

21 See table 5
2 Rev. Charles Candy

4. One married three times without issue

- Three sibs married 3 unrelated sibs

8 One killed in war

10 Not all traceable

12 One killed

14 Jewish : $m$. in Jamaica

16 See table I3

18 Two killed

20 See table 4 
in the second. Nor are the families concerned or the propositi aware of the genetic theory which distinguishes the two groups. The bias which I am inclined to suspect, not a severe one, favours bimodality or bipolarity. People are naturally interested in demonstrating the extremes which are most effectively demonstrable, whether these prove or disprove the hypothesis proposed to them.

TABLE 2A (continued)

\begin{tabular}{|c|c|c|c|c|c|c|c|c|c|c|}
\hline \multirow{2}{*}{ Name } & \multirow{2}{*}{ No. } & \multicolumn{4}{|c|}{ c } & \multicolumn{4}{|c|}{ gc } & \multirow{2}{*}{$\frac{\text { ggc }}{t}$} \\
\hline & & $t$ & $\mathrm{~s}$ & $\mathrm{~m}$ & wi & $t$ & $\mathrm{~s}$ & $\mathrm{~m}$ & wi & \\
\hline $\begin{array}{l}\text { Totals } \\
\mathrm{I}-6 \\
\mathrm{cpm}(\dot{w i}) \\
\text { cp original } \mathrm{m}\end{array}$ & $24 \mathrm{~m}$ & $\begin{array}{r}97 \\
4^{\circ} \cdot \\
4^{\circ} 0\end{array}$ & 78 & 53 & 35 & $\begin{array}{c}126 \\
3.6 \\
5.3(>\end{array}$ & $\begin{array}{l}102 \\
(1 \cdot 3)\end{array}$ & 80 & 67 & $\begin{array}{l}164+ \\
2 \cdot 45 \\
6 \cdot 8(\times 1 \cdot 7)\end{array}$ \\
\hline $\begin{array}{l}\text { Percentage passing } \\
\text { successive tests }\end{array}$ & & $\ldots$ & $\frac{80}{3^{6}}$ & $\underbrace{68}_{\text {oer } c e}$ & 66 & ... & $\underbrace{8 \text { I }}_{53}$ & $\underbrace{78}_{\text {per ce }}$ & 84 & $\ldots$ \\
\hline $\begin{array}{l}7-15 \\
\operatorname{cpm}(\dot{w i}) \\
\text { cp original } m\end{array}$ & I $5 \mathrm{~m}$ & $\begin{array}{l}I 37 \\
9^{\cdot I} \\
9^{\cdot} I\end{array}$ & 107 & 68 & 59 & $\begin{array}{r}216 \\
3.7 \\
14 \cdot 4(x\end{array}$ & $\begin{array}{l}168 \\
1 \cdot 6)\end{array}$ & ${ }^{1} 32$ & 305 & $\begin{array}{c}335+ \\
3 \cdot 2 \\
22 \cdot 3(\times 2 \cdot 5)\end{array}$ \\
\hline $\begin{array}{l}\text { Percentage passing } \\
\text { successive tests }\end{array}$ & & $\ldots$ & $\underbrace{78}_{43}$ & $\underbrace{64}_{\text {oer } c e}$ & 87 & $\ldots$ & $\underbrace{78}_{4^{8}}$ & $\underbrace{78}_{\text {per ce }}$ & 79 & \\
\hline $\begin{array}{l}\text { GRAND Totals } \\
\text { cpm (wi) } \\
\text { cp original m }\end{array}$ & $39 \mathrm{~m}$ & $\begin{array}{l}234 \\
6 \cdot 0 \\
6 \cdot 0\end{array}$ & 185 & I2I & 94 & $\begin{array}{c}342 \\
3 \cdot 6 \\
8 \cdot 8(>\end{array}$ & $\begin{array}{l}270 \\
(1 \cdot 5)\end{array}$ & 212 & I 72 & $\begin{array}{c}499+ \\
2 \cdot 9 \\
12 \cdot 8(\times 2 \cdot 1)\end{array}$ \\
\hline $\begin{array}{l}\text { Percentage passing } \\
\text { successive tests }\end{array}$ & & $\cdots$ & $\underbrace{79}_{4 \mathrm{c}}$ & $\begin{array}{r}66 \\
\text { per } \mathrm{c}\end{array}$ & $77^{*}$ & $\ldots$ & $\underbrace{79}_{50}$ & 78 & $8 \mathrm{I} *$ & $\cdots$ \\
\hline
\end{tabular}

* The 195 I British Census records as having had live-born children 88 per cent. of all marriages that have lasted over I 5 years (Campbell, I958), i.e. I 2 per cent. of sterility.

This interest in simple demonstration is responsible perhaps for the clear statement of causes of the depression in survival, marriage and fertility in the first generation in table 2A.

The causes of the depression effect that are given by correspondents for each of the three stages of the life-cycle that I have distinguished include the following:

I. Survival: pyloric stenosis, epilepsy, diabetes, cancer.

2. Marriage: blindness, intersexuality, insanity, lack of interest in the opposite sex, or in either sex. 
3. Reproduction: (in women) acute dysmenorrhœa, toxæmia of pregnancy, miscarriage and difficult parturition (leading in one family to Cæesarean section in mother and daughter).

Defects such as blindness (e.g. in table 3 ) are no doubt often due to the segregation of major-gene recessives so well known in cousin marriages. The majority of defects, however, escape classification. One of these classes, which is increased in the progeny of table 2A,

TABLE 2B

Families from small-groups or with successive cm (omitting DTM)

\begin{tabular}{|c|c|c|c|c|c|c|c|c|c|c|}
\hline \multirow{2}{*}{ Name } & \multirow{2}{*}{ Date } & \multicolumn{4}{|c|}{$c$} & \multicolumn{4}{|c|}{ gc } & \multirow{2}{*}{$\frac{\text { ggc }}{t}$} \\
\hline & & $\mathrm{t}$ & $\mathrm{s}$ & $\mathrm{m}$ & wi & $\mathrm{t}$ & $\mathbf{s}$ & $\mathrm{m}$ & wi & \\
\hline $\begin{array}{l}\text { Grubb }{ }^{1} \\
\text { Spencer }{ }^{2}: \\
\text { Gilpin }(6 a)^{3}: \\
\text { Davies }{ }^{4}: \\
\text { \{T. F. Buxton }{ }^{5} \\
\text { "E. N. Buxton }{ }^{8} \\
\text { "White" }{ }^{7}: \\
\text { Butland } 8: \\
\text { Shewell }{ }^{9}:\end{array}$ & $\begin{array}{r}1879 \\
\text { c. } 1790 \\
1855 \\
1835 \\
1845 \\
1835 \\
1870 \\
1858 \\
1874\end{array}$ & $\begin{array}{r}3 \\
4 \\
4 \\
5 \\
5 \\
7 \\
7 \\
\mathrm{II} \\
\mathrm{II}\end{array}$ & $\begin{array}{r}3 \\
4 \\
3 \\
4 \\
5 \\
6 \\
6 \\
10 \\
9\end{array}$ & $\begin{array}{l}2 \\
3 \\
2 \\
1 \\
4 \\
6 \\
6 \\
8 \\
5\end{array}$ & $\begin{array}{l}2 \\
2 \\
2 \\
1 \\
4 \\
6 \\
6 \\
7 \\
5\end{array}$ & $\begin{array}{r}5 \\
7 \\
10 \\
14 \\
20 \\
38 \\
17 \\
17 \\
18\end{array}$ & $\begin{array}{r}5 \\
6 \\
9 \\
9 \\
19 \\
36 \\
17 \\
17 \\
18\end{array}$ & $\begin{array}{l}4 \\
4 ? \\
5 \\
5 \\
15 \\
28 \\
14 \\
11 \\
15\end{array}$ & $\begin{array}{c}3 \\
4 \\
5 \\
5 \\
10 \\
20 \\
12 \\
8 \\
12+\end{array}$ & $\begin{array}{l}10 \\
17 \\
17 \\
22 \\
39 \\
62 \\
35+ \\
23 \\
3^{2}+\end{array}$ \\
\hline $\begin{array}{l}\text { Total } \\
\text { cpm (wi) } \\
\text { cp original m }\end{array}$ & $9 \mathrm{~m}$ & $\begin{array}{l}57 \\
6 \cdot 3 \\
6 \cdot 3\end{array}$ & $5^{\circ}$ & 37 & 35 & \begin{tabular}{c|}
146 \\
$4 \cdot 2$ \\
$16 \cdot 2$
\end{tabular} & $\begin{array}{r}13^{6} \\
2 \cdot 6)\end{array}$ & IOI & $79+$ & $\begin{array}{c}257+ \\
28 \cdot 6 \stackrel{3 \cdot 3}{(\times 4 \cdot 5)}\end{array}$ \\
\hline $\begin{array}{l}\text { Percentage passing } \\
\text { succesive tests }\end{array}$ & & $\ldots$ & $\underbrace{88}_{\epsilon}$ & 74 & $\mathcal{L}^{95}$ & $\cdots$ & $9 \underbrace{3}_{5}$ & $\underbrace{74}$ & $\frac{79}{\text { tt. }}+$ & $\cdots$ \\
\hline
\end{tabular}

1 Irish Quaker family

3 See table 6

5 See table io

7 See table 14

- Quaker family
2 Spouses gc of the 3rd D. of Marlborough

$4 \mathrm{Scm}$ : two common gps were first cousins

- See table io

8 White Bermudian family

is that of those who reach mature years but do not marry: they prefer celibacy.*

They are due to the production of new and untested combinations. When such combinations are unfavourable we are accustomed to refer to them as examples of unbalance. But here precisely the same process gives rise to a small proportion of individuals- 5 to io per cent. - scattered through the children of cousin marriage progenies in outbred stocks whose fertility is not depressed but enhanced.

* Galton (1869) considered, not unreasonably, that the celibacy of the mediæval clergy, so far as it was respected, prevented the proportionate breeding of a useful fraction of society to the disadvantage of succeeding generations. But between io and 20 per cent. of most populations never breed in any case although no vows of celibacy are imposed upon them. In so far as they fail to breed for genetic reasons it follows that the vow is secondary, the genotype is primary. They make a virtue of necessity, and only our instinctive belief in the power of free will has prevented our recognising the sequence of events. 
The consequence of this recombination is that while the children in the inbred stocks are fairly uniform in behaviour, those in the outbred stocks show an extravagant range of variation. It is seen within large families and between small ones. On the one hand, in table 2B, there are the Grubb, Buxton, Shewell and Butland families, homogeneous and steadily expanding, some slowly, some rapidly. On the other hand, in table 2A there are the Brown, Candy and King families where most sibs do not marry or have no offspring while others have

TABLE 3

Descendants of Thомаs Nock, b. I829, m. 1850, Sophia Johnson, half cousin

\begin{tabular}{|c|c|c|c|c|c|c|c|c|c|c|c|}
\hline \multicolumn{5}{|c|}{ c } & & & \multicolumn{4}{|c|}{ gc } & \multirow{2}{*}{$\frac{\text { ggc }}{t}$} \\
\hline $\mathrm{t}$ & $s$ & $\mathrm{~m}$ & wi & & born & $\mathrm{m}$ & $t$ & $\mathrm{~s}$ & $\mathrm{~m}$ & wi & \\
\hline \multirow[t]{3}{*}{$14^{1}$} & 9 & 7 & 7 & \multirow{3}{*}{$\begin{array}{r}0 \\
0 \\
0 \\
0 \\
0 \\
0 \\
10 \\
10 \\
0 \\
0\end{array}$} & $\begin{array}{l}185 \mathrm{I} \\
1853\end{array}$ & $\begin{array}{r}1871 \\
1869\end{array}$ & \multirow{2}{*}{$\begin{array}{r}10 \\
12 \\
8 \\
3 \\
5 \\
3 \\
4^{4}\end{array}$} & \multirow{2}{*}{$\begin{array}{l}5 \\
6 \\
5 \\
2 \\
5 \\
3 \\
1\end{array}$} & \multirow{2}{*}{$\begin{array}{c}5 \\
2 \\
5 \\
2 \\
5 \\
3 \\
1\end{array}$} & \multirow{2}{*}{$\begin{array}{l}5 \\
2 \\
5 * \\
2 \\
5 \\
2 \\
1\end{array}$} & \multirow{2}{*}{$\begin{array}{c}13^{2} \\
10 \\
6 \\
3 \\
7 \\
3^{3} \\
6\end{array}$} \\
\hline & & & & & $\begin{array}{l}1864 \\
1864 \\
1865 \\
1865\end{array}$ & $\begin{array}{l}1802 \\
1889 \\
1890 \\
1897 \\
1899\end{array}$ & & & & & \\
\hline & & & & & \multicolumn{2}{|c|}{ Total } & 45 & 27 & 23 & 22 & $4^{8}$ \\
\hline
\end{tabular}

1 Includes six born blind, unmarried; also one pair two-egg twins (bracketed, b. I 865). Excludes two pairs twins born dead.

2 Includes two pairs of twins.

3 Includes one pair of twins : one married a twin and had twins in 1957.

4 Includes one born blind.

Notes : (i) High fertility and twinning combined with reproduction impaired by a visible defect arising from $\mathrm{cm}$.

(ii) Drop in birth rate after 1890 coincides with drop in infant mortality.

* Source : Mr Walter Wilson of Ulverston.

up to nineteen children. Similarly in the Henderson pedigree (table I 5B, 2a).

Our division, of course, is arbitrary. As we saw, there must be a continuous gradation between the extremes. We find the intermediate situation in the Trench family belonging to the Anglo-Irish landowning class which has no doubt been moderately inbred for 250 years (tables 2A and 4). We also find it in the Davies family which does not come from an inbred group but merely has one earlier cousin marriage (table 2B). And finally in the Walker family (tables 2A and 5) with no particular evidence of prior inbreeding we have a pedigree of the uniform type. These difficulties of classification, however, do not prevent me thinking that the modes are near the extremes and the intermediates are less abundant. 
Now, in the inbred stocks which fail to show an inbreeding depression, it would seem that there is not enough heterogeneity present to

\section{TABLE 4}

Descendants of Righard Chenevix Trench (1807-86), Archbishop of Dublin, m. 1832, first cousin, Hon. Frances Mary Trench (I809-9o)

\begin{tabular}{|c|c|c|c|c|c|c|c|c|c|c|}
\hline \multirow[b]{2}{*}{ Name } & \multirow[b]{2}{*}{ Date } & \multicolumn{4}{|c|}{$c$} & \multicolumn{4}{|c|}{ gc } & \multirow{2}{*}{$\frac{\text { ggc }}{t}$} \\
\hline & & $\mathrm{t}$ & $\mathrm{s}$ & $\mathrm{m}$ & wi & $\mathrm{t}$ & $\mathrm{s}$ & $\mathrm{m}$ & wi & \\
\hline \multirow[t]{3}{*}{ Trench } & 1832 & $14^{1}$ & I0 & 8 & 6 & \multirow{2}{*}{$\begin{array}{l}6 \\
5 \\
8 \\
3 \\
7 \\
6\end{array}$} & \multirow{2}{*}{$\begin{array}{l}4 \\
5 \\
7 \\
3 \\
7 \\
5\end{array}$} & \multirow{2}{*}{$\begin{array}{l}3 \\
3 \\
6 \\
2 \\
5 \\
4\end{array}$} & \multirow{2}{*}{$\begin{array}{l}1 \\
2 \\
5 \\
1 \\
3 \\
3\end{array}$} & \multirow{2}{*}{$\begin{array}{c}3 \\
2+ \\
34 \\
5 \\
4+ \\
7\end{array}$} \\
\hline & & & & & & & & & & \\
\hline & & & & & & 35 & $3 \mathrm{I}$ & 23 & I 5 & $35+$ \\
\hline
\end{tabular}

18 sons, 6 daughters.

Source: Mr C. E. F. Trench, Drogheda, Eire.

TABLE 5

Descendants of Dr Thomas JAmes WALKer of Peterborough (1835-1916), m. c. I867, his first cousin, Mary Elizabeth Walker (1845-1915) daughter of the Vicar of Newmarket

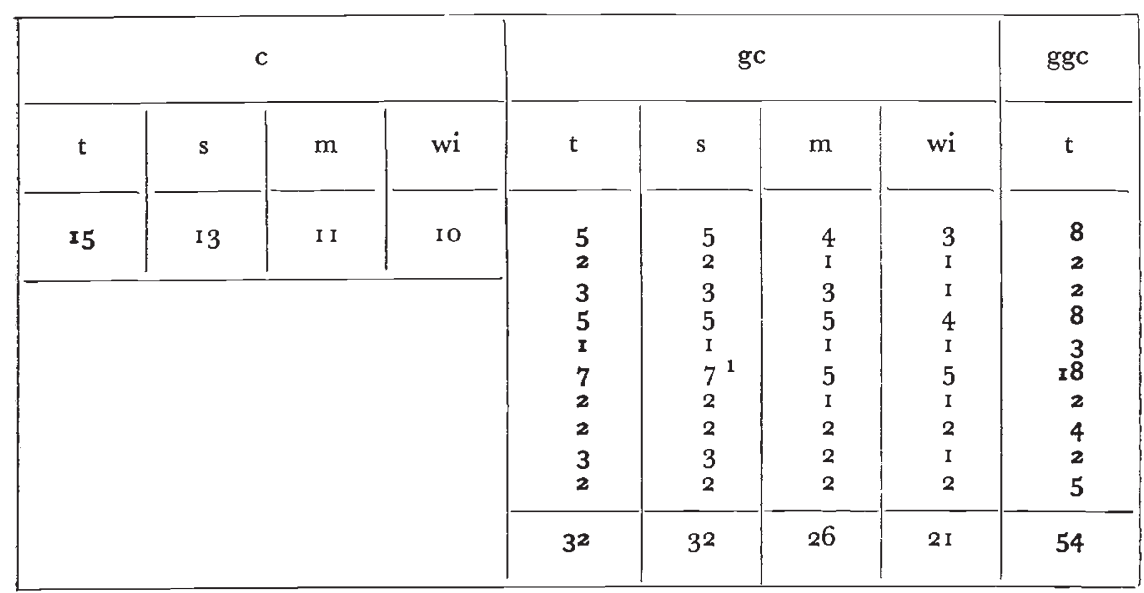

1 One injured in spine in 1914 war, unmarried.

Source: Mrs Freda Gill, Chesterwood Grange, Hexham.

cause a high proportion of unfavourable combinations to appear on inbreeding. Or to put the matter in another way, the unfavourable combinations so far as they concern fertility have already been cleaned out of these stocks. 
To test this view I have examined the different kinds of conditions under which inbreeding develops and its effects on fertility. We may roughly but conveniently distinguish three kinds of situation:

(i) Social or economic origin.

(ii) Religious origin.

(iii) Royal families where assortative mating and even natural selection to some extent lapse.

There is of course no limit to the number of such stable systems that could be studied in different parts of the world. It is, however, the systems that exist in Europe that are of the most interest, on account of their instability and also their documentation.

\section{INBRED GROUPS}

\section{(i) Social or economic inbreeding}

The development of cousin marriages may be readily followed from the prolific Gilpin and Wedgwood pedigrees. In the Gilpin family the first cousin marriage extracted, following heavy elimination, fertile strains, i.e. favourable recombinations. In these, after an interval of one generation, further cousin marriages occurred, one being between double first cousins. The Wedgwood family began, in this respect, with a third-cousin marriage which was followed, after an interval of two generations, by four cousin marriages, one again being between double first cousins. Here the third-cousin marriage does not seem to have mitigated the effects of the subsequent inbreeding, for the survival and fertility of the children was low. Only in one family, the descendants of Charles Darwin, has a highly fertile strain emerged from the recombination (tables 6 and 7).

The descendants of the Rev. Charles Candy (180o-189o) (table 2A) show similarly the pattern by which successive cousin marriages originate. He married his first cousin and the result was typical of cousin marriage in an outbred stock. They had four sons; three survived, two married, but only one had issue. This was Herbert Candy (I832-1 893) who married twice, once a near relative, Margaret Spence (five children), and once an unrelated daughter of a cousin marriage, Mary Davies (fourteen children). Hence from this one surviving child were descended twenty-eight great-grandchildren.

Thus we have the emergence of highly fertile stocks capable of further inbreeding from only single individuals among the offspring of cousin marriage in outbred stocks. These we may call foundermarriages. They have their origins in special social, economic, and intellectual situations. Such marriages are seen establishing new lines in the Gilpin, Wedgwood and Candy, and also in the White and the Brown families. The proportions of these successes seem to be small. But they show us how the persistent inbred groups in Quakers, Jews and Royal families probably began. 
TABLE 6

Successive cousin marriages

The Gilpin family of Scaleby Castle, Cumberland, by generations

I. William Gilpin (I657-1 724) m. Mary Fletcher (b. I654)

3. Rev. Wm. Gilpin (I 724-1804) m. Margaret Gilpin (I 725-1807)

4. Rev. Wm. Gilpin (1 757-1848) m. Elizabeth Farish (1 760-1831)

6a. Richard Brownlow Benson (b. 1831) m. Eliz. Barbara Gilpin (b. 1830)

6b. Charles Benson (1826-19 I I) m. Henrietta Emily Gilpin (1832-188o)

\begin{tabular}{|c|c|c|c|c|c|c|c|c|c|c|}
\hline \multirow{2}{*}{$\begin{array}{c}\text { Genera- } \\
\text { tion }\end{array}$} & \multirow{2}{*}{ Date } & \multicolumn{4}{|c|}{ c } & \multicolumn{4}{|c|}{ gc } & \multirow{2}{*}{$\begin{array}{c}\text { ggc } \\
\mathrm{t}\end{array}$} \\
\hline & & $t$ & $\mathrm{~s}$ & $\mathrm{~m}$ & wi & $\mathrm{t}$ & $\mathrm{s}$ & $\mathrm{m}$ & wi & \\
\hline I & I 688 & II & 8 & 6 & 4 & 29 & I5 & IO & $7^{1}$ & c. $39^{2}$ \\
\hline $3^{3}$ & I 753 & 4 & 2 & 2 & 2 & $26^{4}$ & 10 & 3 & 2 & 12 \\
\hline 4 & c. 1785 & I 5 & 10 & 3 & 2 & 12 & 9 & 8 & $7^{5}$ & 42 \\
\hline $\int 6 a$ & I 855 & 4 & 3 & 2 & 2 & ro & 9 & 5 & 5 & 17 \\
\hline$\{6 b$ & c. 1856 & 7 & 6 & 3 & 2 & 12 & 12 & $8+$ & $8+$ & $18+$ \\
\hline
\end{tabular}

1 Including both parents in 3 . 2 Including both parents in 4.

3 Double first cousins. 4 One of the two families is untraced after birth.

5 Including both parents in both $6 a$ and $6 b$, which were parallel : two brothers

to two sisters.

Source: Mr George Benson, of Highgate West Hill.

TABLE 7

Successive cousin marriages of the WEDGWOOD family, descended from JosiaH WEDGWOOD I (I730-95) of Etruria, who married in I760, Sarah Wedgwood (I734-1815) his third cousin

\begin{tabular}{|c|c|c|c|c|c|c|c|c|c|c|c|c|}
\hline \multirow{2}{*}{$\begin{array}{l}\text { Gener- } \\
\text { ation }\end{array}$} & \multirow{2}{*}{\multicolumn{2}{|c|}{ Husband }} & \multirow{2}{*}{ Date } & \multicolumn{4}{|c|}{$c$} & \multicolumn{4}{|c|}{ gc } & \multirow{2}{*}{$\begin{array}{r}\text { ggc } \\
\mathrm{t}\end{array}$} \\
\hline & & & & $\mathrm{t}$ & $\mathrm{s}$ & $\mathrm{m}$ & wi & $\mathrm{t}$ & $s$ & $\mathrm{~m}$ & wi & \\
\hline I & Josiah W. I . & . & I $73^{0}-95$ & 8 & 6 & 3 & 3 & 22 & 20 & I 3 & II $^{1}$ & $64^{2}$ \\
\hline $\begin{array}{l}3^{a} \\
3^{b} \\
3^{c} \\
3^{d}\end{array}$ & $\begin{array}{l}\text { Charles Darwin } \\
\text { Hensleigh W. } \\
\text { Henry Allen W. } \\
\text { Josiah W. III . }\end{array}$ & $\dot{.}$ & $\begin{array}{l}\text { 1 } 809-84 \\
\text { I } 803-91 \\
\text { I } 799-1885 \\
\text { I } 795-1880\end{array}$ & $\begin{array}{r}\text { ro } \\
6 \\
5 \\
4\end{array}$ & $\begin{array}{l}7 \\
6 \\
5 \\
3\end{array}$ & $\begin{array}{l}6 \\
4 \\
4 \\
2\end{array}$ & $\begin{array}{l}3 \\
3 \\
2 \\
2\end{array}$ & $\begin{array}{l}9 \\
5^{3} \\
8 \\
7\end{array}$ & $\begin{array}{l}9 \\
4 \\
8 \\
7^{5}\end{array}$ & $\begin{array}{l}8 \\
3 \\
4 \\
5\end{array}$ & $\begin{array}{l}7 \\
2 \\
1 \\
2\end{array}$ & $\begin{array}{r}28 \\
7 \\
2 \\
7\end{array}$ \\
\hline 4 & Godfrey W. ${ }^{6}$ & . & $1833-1905$ & I & I & I & o & $\cdots$ & & & & \\
\hline 6 & Josiah C. W. ${ }^{7}$. & . & I $872-1943$ & 7 & 7 & 5 & 4 & 14 & 12 & $6+$ & $\cdots$ & $18+$ \\
\hline $3^{a-d}$ & Total & . & $\cdots$ & 25 & 21 & I 6 & 10 & 29 & 28 & 20 & I 2 & 44 \\
\hline
\end{tabular}

1 Two gc married unrelated wives and had no issue.

2 Doubling the 19 ggc who were descended in two lines owing to $\mathrm{cm}$.

3 One killed at 22.

4 A double Ist $\mathrm{cm}$ : it produces fewer ggc than other $\mathrm{cm}$ except 4 .

5 Two of these 7 were killed (one at 34 unmd, one at 33 with $3 \mathrm{ch}$. i.e. fertility curtailed).

6 Married a daughter of $3 b$, i.e. of a cm. This was a second marriage (see double test marriages).

7 Ist Baron Wedgwood.

${ }_{6,7}$ descended from no previous $\mathrm{cms}$ since Josiah W. I.

Source: Hon. Mrs Helen Pease of Cambridge. 


\section{(ii) Religious minorities}

Jewish communities in Europe seem until recently to have been closely inbred. This was partly due to their position as a strict religious minority of great antiquity and partly to their discriminating social stratification. The distribution of cousin marriages in a particular group long residing in the region of Birmingham is shown in table 8.

TABLE 8

Distribution of 32 cousin marriages in the Joseph connection by degrees

\begin{tabular}{|c|c|c|c|c|c|c|c|c|c|}
\hline Ist & I.5 & 2nd & 2.5 & 3 rd & 3.5 & 4 th & 4.5 & 5.5 & 6.5 \\
\hline I0 & I & 7 & I & I & 3 & 3 & 4 & I & I \\
\hline
\end{tabular}

It indicates a preference for close over less close inbreeding. The results (in table 9) are regular. They are so regular that we can see the fall in numbers of progeny from generation to generation strictly

TABLE 9

Ten marriages of first cousins in the Foseph connection

\begin{tabular}{|c|c|c|c|c|c|}
\hline \multirow{2}{*}{ No. } & \multirow{2}{*}{ Date } & \multicolumn{3}{|c|}{ c } & \multirow{2}{*}{$\frac{\mathrm{gc}}{\mathrm{t}(\mathrm{cpm})}$} \\
\hline & & $\mathrm{t}(\mathrm{cpm})$ & $\mathrm{m}$ & wi & \\
\hline \multirow[t]{2}{*}{$\begin{array}{l}\text { I. } \\
2 . \\
3 . \\
4 . \\
5 .\end{array}$} & $\begin{array}{l}\text { c. } 1800 \\
\text { c. } 1810 \\
\text { c. } 1844 \\
\text { c. } 1855 \\
\text { c. } 1860\end{array}$ & $\begin{array}{r}10 \\
4 \\
3 \\
3 \\
8\end{array}$ & $\begin{array}{r}4 \\
3 \\
\cdots \\
I \\
4\end{array}$ & $\begin{array}{r}4 \\
2 \\
\ldots \\
1 \\
4\end{array}$ & $\begin{array}{r}27 \\
4 \\
\ldots \\
1 \\
14\end{array}$ \\
\hline & Total & $28(5 \cdot 6)$ & I 2 & I I & $46(4 \cdot 2)$ \\
\hline \multirow[t]{2}{*}{$\begin{array}{r}6 . \\
7 . \\
8 . \\
9 . \\
10 .\end{array}$} & $\begin{array}{l}\text { c. } 1876 \\
\text { c. } 1880 \\
\text { c. } 1895 \\
\text { c. } 1904 \\
\text { c. } 1906\end{array}$ & $\begin{array}{l}4 \\
1 \\
3 \\
3 \\
2\end{array}$ & $\begin{array}{l}2 \\
1 \\
3 \\
3 \\
\text { I }\end{array}$ & $\begin{array}{r}2 \\
\ldots \\
3 \\
2 \\
\ldots\end{array}$ & $\begin{array}{r}5 \\
\ldots \\
6 \\
7 \\
\ldots\end{array}$ \\
\hline & Total & $3(2 \cdot 6)$ & IO & 7 & I $8(2 \cdot 6)$ \\
\hline
\end{tabular}

Source : Mr Anthony Joseph, Trinity College, Cambridge.

in keeping with the national trend. And there is no depression produced by the cousin marriage.

The same result is shown by the Buxton family records (table io). This family is derived from two closely inbred communities, the Quakers and the Independents. The two marriages shown are between 
two pairs of siblings. Again they show high regularity, with a fall in numbers of gc in keeping with the national trend, and no fall in fertility between the parents and the children.

TABLE Io

Parallel first cousin marriages of sibs in an inbred community (incomplete data)

A. Edward North Buxton, 2nd Bart. (1813-1895) m. 1835 Catherine Gurney

\begin{tabular}{|c|c|c|c|c|c|c|c|c|}
\hline \multicolumn{4}{|c|}{ c } & \multicolumn{4}{|c|}{ gc } & \multirow{2}{*}{$\frac{\mathrm{ggc}}{\mathrm{t}}$} \\
\hline$t$ & $\mathrm{~s}$ & $\mathrm{~m}$ & wi & $t$ & $\mathbf{s}$ & $\mathrm{m}$ & wi & \\
\hline \multirow[t]{3}{*}{8} & 8 & 8 & 8 & $\begin{array}{l}10 \\
10\end{array}$ & $\begin{array}{l}\text { Io } \\
\text { I0 }\end{array}$ & & $\begin{array}{l}8 \\
6\end{array}$ & $\begin{array}{l}29 \\
23\end{array}$ \\
\hline & & & & $\begin{array}{l}7 \\
4 \\
2 \\
7 \\
3 \\
5\end{array}$ & $\begin{array}{l}0 \\
4 \\
2 \\
7 \\
3 \\
2+\end{array}$ & $\begin{array}{l}5 \\
3 \\
1 \\
6 \\
3 \\
2+\end{array}$ & $\begin{array}{l}4 \\
2 \\
1 \\
2 \\
3 \\
2+\end{array}$ & $\begin{array}{r}14 \\
5 \\
4 \\
5 \\
6 \\
4+\end{array}$ \\
\hline & Total & . & . & $4^{8}$ & $45+$ & $3^{6+}$ & $28+$ & $90+$ \\
\hline
\end{tabular}

B. Thomas Fowell Buxton (I821-1908) m. I848 Rachel Jane Gurney

\begin{tabular}{|c|c|c|c|c|c|c|c|c|}
\hline \multicolumn{4}{|c|}{ c } & \multicolumn{4}{|c|}{ gc } & \multirow{2}{*}{$\frac{\text { ggc }}{\mathrm{t}}$} \\
\hline$t$ & $s$ & $\mathrm{~m}$ & wi & $t$ & $\mathbf{s}$ & $\mathrm{m}$ & wi & \\
\hline \multirow[t]{3}{*}{ II } & I I & 9 & 8 & 7 & 7 & 5 & 5 & 25 \\
\hline & & & & $\begin{array}{l}5 \\
5 \\
6 \\
7\end{array}$ & $\begin{array}{l}4 \\
5 \\
6 \\
7\end{array}$ & $\begin{array}{l}3 \\
3 \\
6 \\
5\end{array}$ & $\begin{array}{l}3 \\
\mathrm{I} \\
4+ \\
5\end{array}$ & $\begin{array}{l}7+ \\
2+ \\
4+ \\
9+\end{array}$ \\
\hline & & & & $4^{I}$ & $4^{\circ}$ & $3^{2}$ & $27+$ & $73+$ \\
\hline
\end{tabular}

(iii) Mennonites or Hutterites

This sect arose in Central Europe in 1528 , and on account of its strict anabaptist principles it has been inbred for over 300 years: the products of outbreeding are excluded. The group early multiplied to about 15,000 but were nearly exterminated by later persecutions. Sixty fled to Russia in I 762 , and of their descendants some returned to Central Europe in I874 while-to avoid military service-about 300 migrated to South Dakota, whence their descendants have spread 
TABLE II

Mennonite pedigree. Shows all male descendants of Moses Göring in male line and all their female children. Probably includes none who died before maturity

\begin{tabular}{|c|c|c|c|c|}
\hline Sex & C & gc (from $4 \sigma^{\pi} \mathrm{c}$ ) & ggc (from $7 \delta^{\star} \mathrm{gc}$ ) & gggc (from $29 \sigma^{\star} \mathrm{ggc}$ ) \\
\hline$\sigma$ & 4 & $\begin{array}{c}4+0+1+4 \\
9(8 \mathrm{~m}, 7 \text { wi })\end{array}$ & $\begin{array}{l}7+6+\mathrm{I}+4+3+5+3 \\
29(29 \mathrm{~m}, 29 \mathrm{wi})\end{array}$ & $\begin{array}{l}2, \mathrm{I}, 2,6, \mathrm{I}, 3,3: 5, \mathrm{o}, 4 \text {, } \\
6,7,8: 2: 2, \mathrm{I}, 2,1: \\
5,6,2: 6, \mathrm{I}, \mathrm{I}, 5,1: \\
4, \mathrm{I}, 2 \\
90 \text { (not all m yet) }\end{array}$ \\
\hline 우 & 5 & $\begin{array}{l}{[4+I+I+6]} \\
\mathbf{I 2}\end{array}$ & $\begin{array}{l}{[2+5+I+4+4+2+I]} \\
\text { 99 }\end{array}$ & $\begin{array}{l}4,6,1,2,2,3,4: 1,1,5 \text {, } \\
5,3,4,: 1: 1,3,3,4: \\
2,3,2: 2,6,4,2,2: \\
2,2,0 \\
80\end{array}$ \\
\hline Total & 9 & $\underset{2 I}{8+I+2}+10$ & $\begin{array}{l}9+1 \mathbf{I}+2+8+7+7+4 \\
48\end{array}$ & $\begin{array}{l}6,7,3,8,3,6,7: 6,1,9, \\
\text { I 1, 10, 12:3: } 3,4,5,5, \\
5: 7,9,4: 8,7,5,7, \\
3: 6,3,2 \\
\text { r70 gggc }\end{array}$ \\
\hline $\begin{array}{l}\text { Estimated period of } \\
\text { birth }\end{array}$ & $\begin{array}{l}\text { I } 787- \\
\text { I } 810\end{array}$ & $1808-1850$ & $1830-1890$ & $1860-1950$ \\
\hline Surviving $\mathrm{c}$ pm & & $\frac{2 \mathrm{I}}{4}=5 \cdot 25$ & $\frac{4^{8}}{8}=6 \cdot 00$ & $\frac{170}{29}=5.86$ \\
\hline
\end{tabular}

Note. Moses Göring of Mömpelsgard (Montbéliard, France) (married $c$. I 785 ). Moved to Einsiedel (Austria), i 79o, Michelsdorf (Poland), I 797, Edwardsdorf (Russia), i 81 5, Waldheim, i 837 . Descendants to Kotusowka, I863, Kansas and Dakota, I 874 .

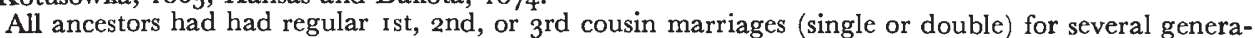
tions. This continued in the pedigree. Thus some would be descended in more than one line from Moses Göring. Only one of these was double in the male line however (i.e. marriages between two Görings). Hence there is little repetition.

Source : Petronella Göring of Vienna IV, 50, Mostgasse 8a.

\section{TABLE IIA}

Progeny in third and fourth generations from Moses Göring showing positive correlation in fertility of successive generations (data in table $I I$ )

\begin{tabular}{|c|c|c|c|}
\hline \multicolumn{2}{|c|}{ Nos. of ggc in 7 families } & \multicolumn{2}{|c|}{ Nos. of gggc from $\delta$} \\
\hline $0+q$ & ర & Total & Mean \\
\hline $\begin{array}{r}2 \\
4 \\
7 \\
7 \\
8 \\
9 \\
\text { I }\end{array}$ & $\begin{array}{l}1 \\
3 \\
3 \\
5 \\
4 \\
7 \\
6\end{array}$ & $\begin{array}{r}2 \\
\text { I I } \\
\text { I } 3 \\
30 \\
\text { I } 7 \\
40 \\
49\end{array}$ & $\begin{array}{l}2 \cdot 0 \\
3 \cdot 7 \\
4 \cdot 3 \\
6 \cdot 0 \\
4 \cdot 3 \\
5 \cdot 7 \\
8 \cdot 2\end{array}$ \\
\hline
\end{tabular}


widely and multiplied to about gooo dispersed in about Ioo village colonies. They have ceased to be a minority; they have become a self-sufficient society. These are now further divided into three separate inbred groups and bear only fourteen family names. Evidence of their reproductive capacity and its evolution comes from two sources.

My first source is the pedigree of the descendants in the male line of Moses Göring (table I I). It will be seen that their net fertility is high and slightly increasing: from 5.25 per marriage to about $6 \cdot 00$ over three generations. Not only this, but hardly any who survive fail to get married and hardly any, indeed latterly none, who marry fail to have issue, the number of issue varying from one to twelve. In this variation the gcs are correlated with their parents (table I IA).

My second source is the admirable account by Eaton and Mayer of the American community, many of whom are descended from Moses Göring. This shows again that the fertility, as recorded by the full birth rate in the $195^{\circ}$ census, is still increasing: from 9.2 to 10.9 per marriage over a period of thirty years. Hence the multiplication of the population nineteen-fold in the last eighty years.

A situation of this kind, high and increasing fertility, should arise if very high fertility (being genetically determined) is selectively advantageous. This is probably not the case in most human societies. The conditions of the Mennonite community in the United States do, however, explain such a selective advantage. These conditions are three-fold: (i) A community adapted by industry and intelligence to the agricultural work which uniformly maintains its progeny and for which opportunities are unlimited. (ii) Regular inbreeding ensuring genetic homogeneity within small groups; since "swarming" takes place when they reach a certain size, these groups maintain a membership of ten to twenty families. (iii) A communistic rule that in the last resort the group is responsible for the aged and the infants in each family. So long as the community prospers therefore and land is unrestricted, children cannot suffer from being too numerous.

We can now examine how these rules apply in other groups.

\section{(iv) Royal families}

The Royal families of Europe resemble the Mennonites in many respects. Like the Mennonites they have inbred and kept the breeding groups small by splitting into inbred sub-groups, the Protestant, the Catholic and the Orthodox. Like the Mennonites, they have outbred occasionally (by morganatic marriages). But they have excluded the products of outbreeding from the group, at least during the golden age with which we are dealing. Like the Mennonites they have not needed to trouble about providing for the offspring. The community will look after that. But, unlike the Mennonites, they are supported by a community which is not their own mating group. It is a whole nation. Selection in Royal families has therefore been much relaxed and the 
TABLE 12

Progeny derived from 37 first cousin marriages between 1764 and 1886

among European Royal families

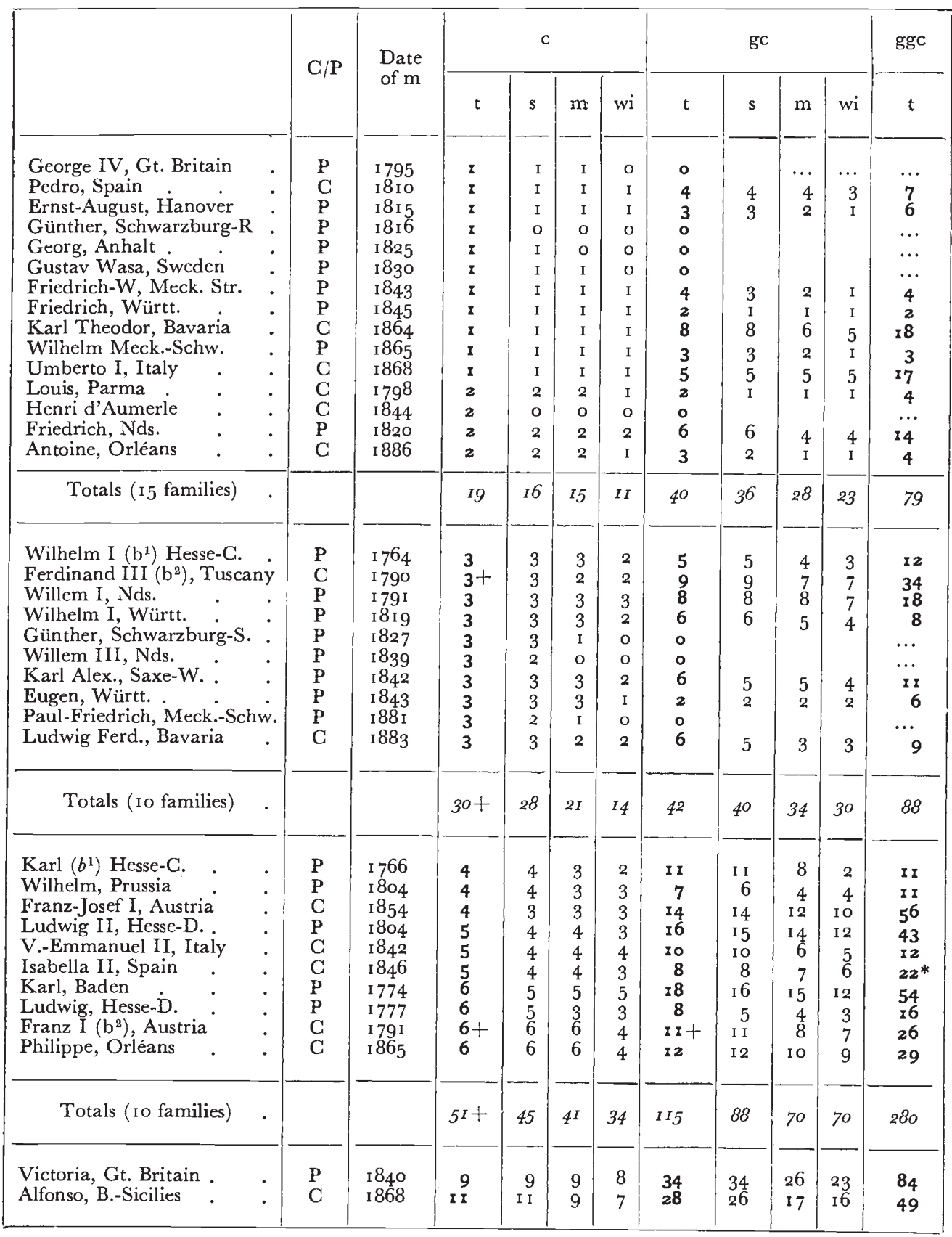

* Numbers of ggc of Isabella and Victoria each include 4 doubled owing to $\mathrm{cm}$ among gcs of the original $\mathrm{cm}$. 
results as shown by our fertility records have been much less uniform than with the Mennonites. Selection is not directed; it is erratic. Fertility is very variable. On the average it is not high. And it does not increase from generation to generation (table I2).

Comparison of the Royal families with the general British population, inbred and outbred, shows the striking constancy of results of the Royal cousin marriages. There is no depression or elevation of the numbers of cpm (wi), which remain 3.4 or 3.5 or of the proportion of successes

SUMMARY OF TABLE I 2

(Royal cm)

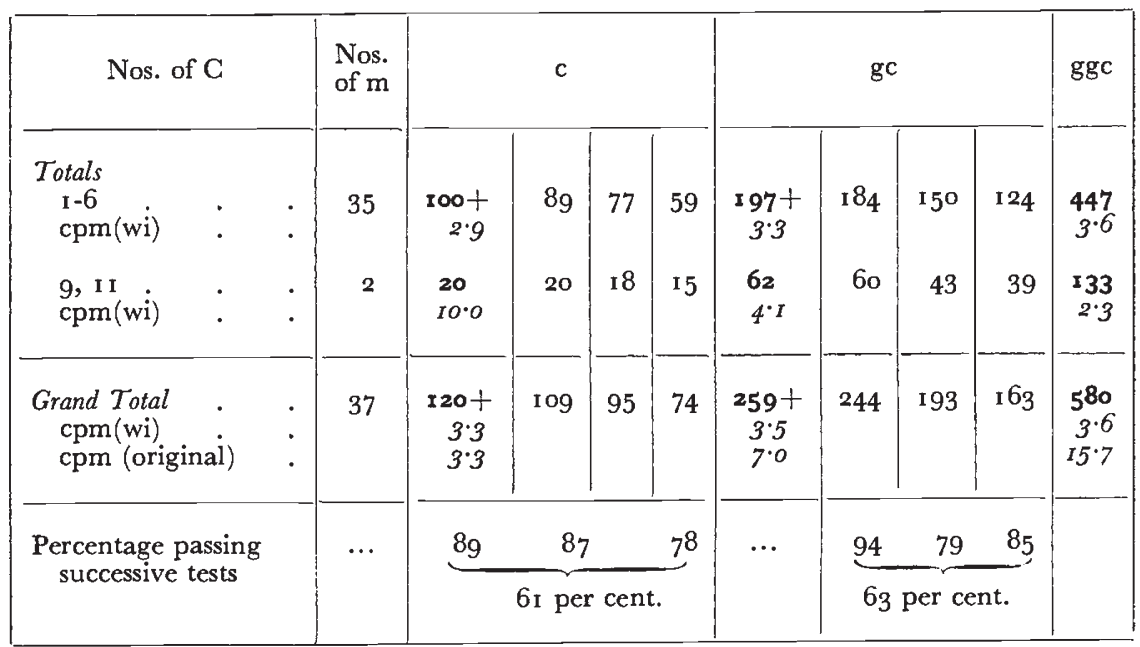

Notes on Table 12

(i) Classified into two main groups, Catholic (14) and Protestant (23).

(ii) Arranged by numbers of children of original marriage.

(iii) Some of the parents are themselves offspring of cousin or uncle-niece marriages.

(iv) Two pairs of brothers show close similarity in numbers of descendants. $b^{1}$ married non-sisters ; $b^{2}$ married sisters.

Source: Mr R. S. Lucas of the University of Nottingham.

in survival, marriage or reproduction between the first and second generation, which remains 61 per cent. or 63 per cent. There is no reason why there should be any change, because all marriages are between cousins of some degree within a homogeneous group, and the distinction between first and second generations therefore lapses.

Royal marriages in the period we are considering were usually political marriages. They should not, therefore, show much biologically valid assortative mating, for example, in fertility. The inheritance of fertility is for this reason perhaps less marked than in the outbred population or the Mennonites. Very fertile lines have appeared, however, in a few of the families. Among these it is worth noting (Mr Lucas tells me) that Don Alfonso of the Bourbon-Sicilies, who had forty-nine ggc, sprang from the same number of twelve ancestors 


\section{TABLE 13}

Parallel marriage test in a homogeneous and fertile outbred family

C Rev. Richard Cockburn Kindersley (1831-71) m. Georgina Anne Kindersley (1838-1927) his first cousin.

$\left.\begin{array}{ll}U_{1} & \text { His only brother } \\ U_{2-6} & \text { His five male cousins }\end{array}\right\}$ married unrelated wives

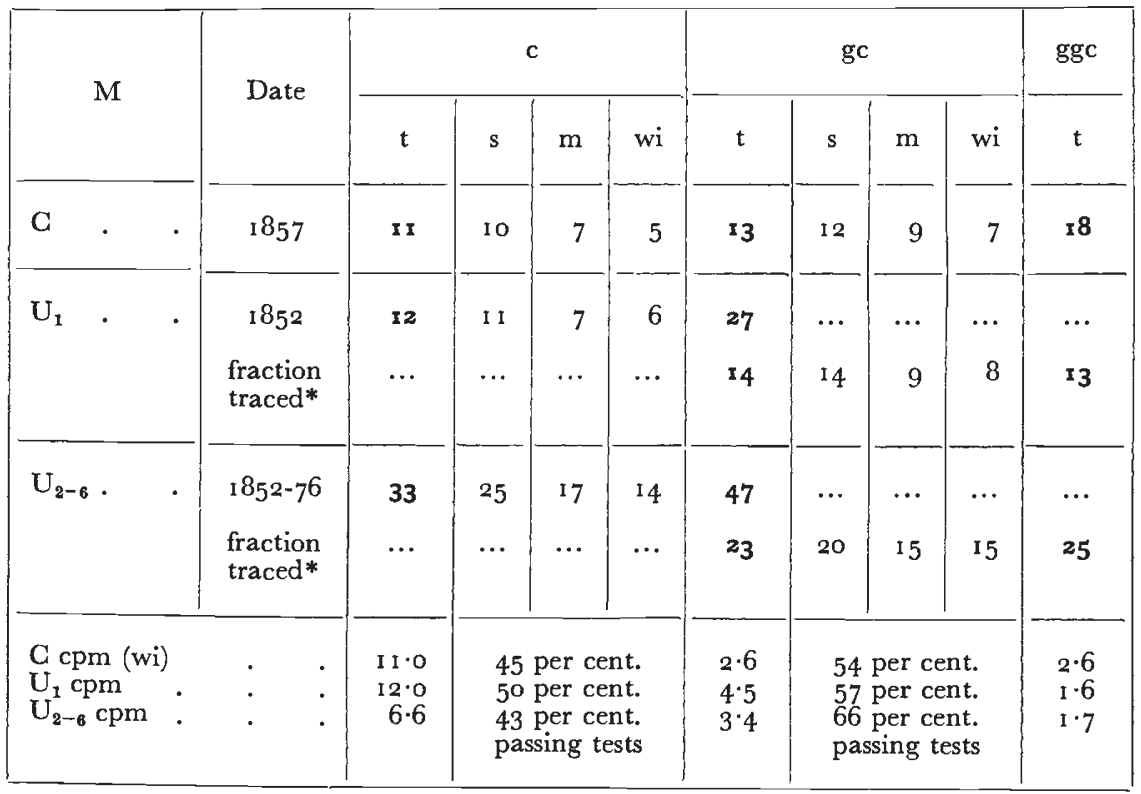

* From male children.

Notes: (i) This is the only $\mathrm{cm}$ recorded in the family since 1700 .

(ii) Higher fertility is recovered in selected gc recombinants of $\mathrm{cm}$.

Source : Mr Richard Kindersley, 5 Eccleston Square, London, S.W.I

TABLE 14

Sib marriage test in the progeny of a cousin marriage in a presumed inbred family

"White" : m. 1870 his first cousin

\begin{tabular}{|c|c|c|c|c|c|c|c|c|}
\hline \multicolumn{4}{|c|}{ c } & \multicolumn{4}{|c|}{ gc } & \multirow{2}{*}{$\frac{\text { ggc }}{t}$} \\
\hline$t$ & $s$ & $\mathrm{~m}$ & wi & $t$ & $\mathrm{~s}$ & $\mathrm{~m}$ & wi & \\
\hline \multirow[t]{3}{*}{7} & $6^{1}$ & 6 & 6 & $\begin{array}{l}4 \\
3^{2}\end{array}$ & $\begin{array}{l}4 \\
3\end{array}$ & $\begin{array}{l}2 \\
3\end{array}$ & $\begin{array}{l}1 \\
2\end{array}$ & ${ }_{3}^{3+}$ \\
\hline & & & & $\begin{array}{l}4 \\
3 \\
x \\
2\end{array}$ & $\begin{array}{l}4 \\
3 \\
1 \\
2\end{array}$ & $\begin{array}{l}3 \\
3 \\
1 \\
2\end{array}$ & $\begin{array}{l}3 \\
3 \\
1 \\
2\end{array}$ & $\begin{array}{l}17 \\
6 \\
2 \\
4+\end{array}$ \\
\hline & & & & 工 7 & 17 & 14 & 12 & $35+$ \\
\hline
\end{tabular}

1 One daughter died : six sons survived.

2 Parents again married first cousins.

Source : Anonymous. 
equally in the $4^{\text {th }}, 5^{\text {th }}$ and 6 th generations (i.e. I2/16, 12/32, 12/64, 22/128). And he married the daughter of an uncle-niece marriage of I850. Similarly the present Comte de Paris, who is descended formally, although not genically, from Charlemagne in perhaps five million ways, has eleven children.

It seems likely that successful inbred groups (of which the Royal caste is merely a convenient and accessible example) have usually arisen not by a sudden adoption of inbreeding - such as we have seen with cousin marriage in our outbred families-but by a gradual contraction of their breeding group, as would happen at the beginning of all religious sects. Where the inbreeding has occurred suddenly there has been a great wastage of resources. Thus in the Ptolemies, the first full brother-sister marriage gave no surviving offspring. Their first successful inbreeding was a half-brother-sister marriage, which was followed by successful full brother-sister marriage.*

\section{PARALLEL SIB-MARRIAGE TESTS}

The parallel in- and out-breeding of sibs offers us the opportunity, as the Kindersley family shows, of making a more significant comparison than that between cousin marriages in different populations (table 13). Although some of the progenies are untraced, the remainder reveal the characteristic contrast in the results of the two types of marriage in an outbred stock.

A second parallel sib-test appeared in an inbred stock. The "White" family have been yeoman farmers in the Exeter district since I60o. They have been Nonconformist, some having been Plymouth Brethren. They should therefore have been subject to inbreeding. Their first known cousin marriage yielded as might be expected a uniform progeny both in viability and fertility (table 14). Of the six who survived all married and all had offspring. But two again married first cousins while four did not. The two inbreeders had twenty grandchildren; the four outbreeders had fifteen grandchildren with the possibility of a few more.

Here we have another indication (agreeing with table 2B) that inbreeding is more fertile in an inbred stock than outbreeding.

\section{DOUBLE TEST MARRIAGES}

We are now prepared to consider the most rigorous method that I have been able to use in studying the relation of fertility to the breeding system. Where a man or a woman has married in succession two spouses, one closely related and the other remotely related, or what is called "unrelated", we can often compare the numbers of descendants and their behaviour in each succeeding generation (table I5A-E).

\footnotetext{
* In this family, however, as in other ancient dynasties, too many princes were begotten and too many died in uncertain circumstances. Even the mother of the last Cleopatra is unrecorded.
} 
TABLE 15

Double test marriages

A. Outbred Stocks

I. Ralph Sadleir, Canon of St Patrick's, Dublin (1815-1902) m. (i) i 839, Letitia Sadleir, first cousin (1818?-1867); (ii) 1871 , Letitia Sewell, unrelated.

\begin{tabular}{|c|c|c|c|c|c|c|c|c|c|c|}
\hline \multirow{2}{*}{$\mathbf{M}$} & \multirow{2}{*}{ Date } & \multicolumn{4}{|c|}{ c } & \multicolumn{4}{|c|}{ gc } & \multirow{2}{*}{$\frac{\text { ggc }}{t}$} \\
\hline & & $t$ & $\mathrm{~s}$ & $\mathrm{~m}$ & wi & $t$ & $\mathbf{s}$ & $\mathrm{m}$ & wi & \\
\hline C & 1 839 & I & I & I & I & 3 & 3 & 2 & 2 & 3 \\
\hline $\mathrm{U}$ & 1871 & I & I & I & I & $I^{1}$ & $\cdots$ & $\ldots$ & $\ldots$ & $\cdots$ \\
\hline
\end{tabular}

1 Burnt to death c. I920.

Source : Colonel B. F. Trench of Halberton, Devon.

2. John Murgatroyd (1819-1876) of Howarth, Yorks $m$. (i) Elizabeth, unrelated i 8201853 ; (ii) Mary Ann, first cousin, $1828-1896$.

\begin{tabular}{|c|c|c|c|c|c|c|c|c|c|c|}
\hline $\mathrm{U}$ & c. $184^{2}$ & 4 & 3 & 3 & 3 & 6 & 6 & 6 & 5 & xo \\
$\mathrm{C}$ & c. $\mathrm{1} 854$ & 6 & $5^{1}$ & 3 & 0 & $\ldots$ & $\ldots$ & $\ldots$ & $\ldots$ & $\ldots$ \\
\hline
\end{tabular}

1 All " eccentric but very alert".

Note--Robert Murgatroyd, father of John, was churchwarden to Patrick Brontë (1777-1861). The family was thus Church of England, a majority group. There were no previous known cousin marriages. It was also a prolific family, Robert having had 48 grandchildren including the ten in this table.

Source : Mrs S. E. Ryan, now in Dublin, a daughter of one of these grandchildren.

3. Anthony, 3Rd Baron Henley (1825-I898) m. (i) Julia Augusta Peel (1826-1862), Ist cousin; ${ }^{1}$ (ii) Glara Jekyll (1838:1922), unrelated.

\begin{tabular}{|c|c|c|c|c|c|c|c|c|c|c|}
\hline $\mathrm{C}$ & 1846 & 6 & 4 & 3 & 2 & 4 & 4 & 3 & $\mathrm{I}$ & 2 \\
$\mathrm{U}$ & 1870 & 3 & 2 & 2 & 2 & 9 & 8 & 8 & 7 & $23+$ \\
\hline
\end{tabular}

1 The common grandfather of the cousin marriage was Sir Robert Peel, Ist Bt., father of the Prime Minister.

Source: The Hon. Michael Eden of Scaleby Castle, Gumberland ; Mr Eden has kindly determined the certain absence of cousin marriage for three generations prior to the cousin marriage in the Henley family and its probable absence in the Peel family.

4. Hugh (1830-1907) m. (i) unrelated wife (1877-1891); (ii) first cousin (1892-1907).

\begin{tabular}{|c|c|c|c|c|c|c|c|c|c|c|}
\hline $\mathrm{U}$ & $\mathrm{I} 877$ & 2 & 2 & 2 & $\mathrm{I}$ & $\mathrm{I}$ & $\mathrm{I}$ & $\mathrm{I}$ & $\mathrm{I}$ & 6 \\
$\mathrm{C}$ & $\mathrm{I} 892$ & 2 & 2 & $\mathrm{I}$ & $\mathrm{O}$ & $\ldots$ & $\ldots$ & $\ldots$ & $\ldots$ & $\ldots$ \\
\hline
\end{tabular}

1 Married three times.

Source : Lady Constance Malleson. 
5. Constance Mary Saltan (1867-1948) m. (i) unrelated husband (1889-1898) ; (ii) first cousin (1898-1 937 ).

\begin{tabular}{|c|c|c|c|c|c|c|c|c|c|c|}
\hline \multirow{2}{*}{$\mathrm{M}$} & \multirow{2}{*}{ Date } & \multicolumn{4}{|c|}{ c } & \multicolumn{4}{|c|}{ gc } & \multirow{2}{*}{$\begin{array}{c}\text { ggc } \\
\mathrm{t}\end{array}$} \\
\hline & & $t$ & $\mathbf{s}$ & $\mathrm{m}$ & wi & $t$ & $s$ & $\mathrm{~m}$ & wi & \\
\hline $\mathrm{U}$ & I 889 & 2 & 2 & 2 & 2 & 4 & 4 & 3 & 3 & 6 \\
\hline C & I 898 & 2 & I & 0 & $\cdots$ & $\cdots$ & $\cdots$ & $\cdots$ & $\cdots$ & $\cdots$ \\
\hline
\end{tabular}

Source : Miss Ann Wadham of Cambridge.

B. INTERMEDIATE (with previous cousin marriages)

I. Godfrey Wedgwood (1833-1905) (cf. table 7) m. (i) c. I86o Mary Hawkshaw, d. I863, unrelated ; (ii) 1 879 , Hope Elizabeth W., first cousin (daughter of $\mathrm{cm}$ ).

\begin{tabular}{|l|c|c|c|c|c|c|c|c|c|c|}
\hline $\mathbf{U}$ & $c .1860$ & $\mathbf{I}$ & $\mathrm{I}$ & $\mathrm{I}$ & $\mathbf{I}$ & $\mathbf{2}$ & 2 & $\mathrm{I}$ & $\mathrm{I}$ & $\mathbf{2}$ \\
$\mathrm{C}$ & $\mathrm{I} 879$ & $\mathrm{I}$ & $\mathrm{I}$ & $\mathrm{I}$ & $\mathrm{O}$ & $\ldots$ & $\ldots$ & $\ldots$ & $\ldots$ & $\ldots$ \\
\hline
\end{tabular}

Source : The Hon. Mrs Helen Pease of Cambridge.

2. The Campbell-Callender Sequence

(a) John Henderson, m. Mary, first cousin, c. I 760.

\begin{tabular}{|l|l|l|l|l|l|l|l|l|l|l|}
\hline $\mathrm{C}$ & 6 & 6 & 6 & 4 & $\mathrm{I3}^{1}$ & $\mathrm{I}^{2}$ & $\mathrm{I}$ & $\mathrm{I}$ & $\mathrm{I}^{3}{ }^{3}$ \\
\hline
\end{tabular}

1 Some went to U.S.A. after I 798 rebellion ; all but one untraced.

2 William Campbell of Derry, only child (1798-1862) on account of his father's emigration.

3 Includes Thomas and Margaret Callender Campbell $(c f .2 b)$ but not their cousinspouses Thomas and Agnes Callender who were not descended from $\mathrm{cm}$ (see table 2A), m. 1858 .

(b) Thomas Callender, b. I $836, m$. (i) Margaret C. Campbell, first cousin c.1865; (ii) Mary McNab, unrelated, c. 1875 .

\begin{tabular}{|c|c|c|c|c|c|c|c|c|c|}
\hline $\mathrm{C}$ & 4 & 3 & 3 & 2 & 6 & 5 & 2 & 2 & 5 \\
$\mathrm{U}$ & $5^{1}$ & 4 & 2 & 2 & 6 & 6 & 4 & 4 & $x_{4}+$ \\
\hline
\end{tabular}

1 Including twins.

Source : Dr Sheila Callender of the Radcliffe Infirmary, Oxford.

3. McLeOd of TAIN (I86I-I 925 ), $m$. (i) I89I, first cousin, daughter of presumed first cousins ; (ii) 1895 , unrelated wife.

\begin{tabular}{|c|c|c|c|c|c|c|c|c|c|c|}
\hline $\mathrm{C}$ & $\mathrm{I} 89 \mathrm{I}$ & 2 & $\mathrm{I}$ & $\mathrm{I}$ & $\mathrm{I}$ & 4 & 4 & 4 & 4 & $8+$ \\
$\mathrm{U}$ & $\mathrm{I} 895$ & 2 & $\mathrm{I}$ & $\mathrm{I}$ & $\mathrm{o}$ & $\ldots$ & $\ldots$ & $\ldots$ & $\ldots$ & $\ldots$ \\
\hline
\end{tabular}

Source : Mrs M. P. Close of Lone Cove, Sydney, Australia. 


\section{INBRED}

(i) Non-Jewish

I. Count Watthier Hamilton (1 783-1835), m. (i) Marie Helena v. Strokirch (1 785-1820) unrelated ; (ii) Hedvig Hamilton (1800-1 859), first cousin.

\begin{tabular}{|c|c|c|c|c|c|c|c|c|c|c|}
\hline \multirow{2}{*}{ M } & \multirow{2}{*}{ Date } & \multicolumn{4}{|c|}{ c } & \multicolumn{4}{|c|}{ gc } & \multirow{2}{*}{$\frac{\text { ggc }}{t}$} \\
\hline & & $\mathrm{t}$ & $\mathrm{S}$ & $\mathrm{m}$ & wi & $\mathrm{t}$ & $\mathbf{S}$ & $\mathrm{m}$ & wi & \\
\hline $\mathrm{U}$ & I8I I & 2 & 2 & 2 & I $^{1}$ & 4 & 2 & 2 & $2^{2}$ & $\left\{\begin{array}{l}9 \\
I\end{array}\right.$ \\
\hline $\mathrm{C}$ & I 821 & 6 & 5 & 4 & 3 & $\begin{array}{l}x \\
4 \\
4\end{array}$ & $\begin{array}{l}\text { I } \\
4 \\
4\end{array}$ & $\begin{array}{l}\text { I } \\
4 \\
3\end{array}$ & $\begin{array}{l}\text { I }^{2} \\
4 \\
3\end{array}$ & $\begin{array}{r}9 \\
\mathbf{1 6} \\
9\end{array}$ \\
\hline
\end{tabular}

$1 \mathrm{~m}$. his first cousin, outside this pedigree.

$2 \mathrm{~m}$. (being half cousins) and had gc, which are counted in each group.

Note. The repeated $\mathrm{cms}$ make comparison difficult in the third generation. The pattern of $\mathrm{cm}$, however, continues the earlier habit of $\mathrm{cm}$ in this family as in Swedish nobility generally ( $c f$. Alström, I 958; Fraccaro, I 958).

Source : Dr Per Selander of Malmö, Sweden.

2. Double Test Marriage with a successive $\mathrm{cm}$ : (i) H. A. v.d. Wall Bake of Amsterdam (I 8ogI 874) ; (ii) A. M. A. v.d. Wall Bake (1852-1940).

\begin{tabular}{|c|c|c|c|c|c|c|c|c|c|c|c|}
\hline I & C & I 833 & 7 & 7 & 7 & $5^{1}$ & I7 & I 7 & I 4 & I3 & 46 \\
\hline \multirow{2}{*}{2} & C & 1877 & 2 & 2 & 2 & 2 & 6 & 6 & 5 & 4 & I4 \\
\hline & $\mathrm{U}$ & I 884 & 3 & 3 & 2 & I & 4 & $4^{2}$ & 3 & 3 & 9 \\
\hline
\end{tabular}

1 One of these is the husband in (2).

2 One of these killed in war, unmarried.

Note. The twice-married spouse is himself of the first generation of a $\mathrm{cm}$. His $\mathrm{cm}$ is thus a successive $\mathrm{cm}$. Moreover, the families concerned belong to a closely inbred community with many previous $\mathrm{cm}$.

Source : F. G. L. O. van Kretschmar of Westcott House, Cambridge.

(ii) Jewish (uncle-niece)

I. DAvid-(I8I 7-I886) Hanover, m. (i) Johanne-(I83I-I867) unrelated; (ii) Rachel(I 843 -I 924$)$ half-niece.

\begin{tabular}{|c|c|c|c|c|c|c|c|c|c|c|}
\hline $\mathrm{U}$ & $\mathrm{I} 862$ & $5^{1,2}$ & $2^{3}$ & $\mathrm{I}$ & $\mathrm{I}$ & 3 & 3 & 2 & 2 & 3 \\
$\frac{1}{2} \mathrm{~N}$ & $\mathrm{I} 868$ & $4^{2}$ & 3 & 3 & 3 & $7^{4}$ & 5 & 5 & 3 & 7 \\
\hline
\end{tabular}

1 Two died of tuberculosis.

3 One died by suicide.

2 One stillborn.

5 Propositus.

4 One died at Auschwitz.

Source: Anonymous, Montreal, Canada. 
2. Hermann Wittner (I848-I926), Mischalenny, Roumania. m. (i) unrelated wife ; (ii) niece $\left(185^{8-1911)}\right.$.

\begin{tabular}{|c|c|c|c|c|c|c|c|c|c|c|}
\hline & \multirow{5}{*}{} & \multicolumn{5}{|c|}{$\mathrm{c}$} & \multicolumn{5}{|c|}{$\mathrm{gc}$} & $\mathrm{ggc}$ \\
\cline { 3 - 9 } & & $\mathrm{t}$ & $\mathrm{s}$ & $\mathrm{m}$ & $\mathrm{wi}$ & $\mathrm{t}$ & $\mathrm{s}$ & $\mathrm{m}$ & $\mathrm{wi}$ & $\mathrm{t}$ \\
\hline $\mathrm{U}$ & $\mathrm{I} 872$ & $\mathbf{3}$ & 3 & 3 & $\mathrm{I}$ & $\mathbf{2}$ & 2 & 0 & $\ldots$ & $\ldots$ \\
$\mathrm{N}$ & $\mathrm{I} 880$ & $\mathbf{4}$ & 3 & 3 & 2 & $\mathbf{5}$ & 5 & 4 & 4 & 7 \\
\hline
\end{tabular}

Source : Mr Frank Selby, of Hatch End, Middlesex.

\section{Double Test Marriages}

Non-first cousins

I. Johann Sebastian Bach (I685-1750), m. (i) Maria Barbara Bach (1684-1720), second cousin ; (ii) Anna Magdalena Wicken (I 70 I-I 760) unrelated.

\begin{tabular}{|c|c|c|c|c|c|c|c|c|c|c|}
\hline $\mathrm{C}_{2}$ & $\mathrm{I} 707$ & 7 & 3 & 2 & 2 & 6 & 3 & 0 & $\ldots$ & $\ldots$ \\
$\mathrm{U}$ & $\mathrm{I} 72 \mathrm{I}$ & $\mathrm{r}_{3}$ & 6 & 3 & 2 & 6 & 4 & 4 & 3 & I0 $^{1}$ \\
\hline
\end{tabular}

${ }^{1} 28 \mathrm{~g}^{3} \mathrm{c}, 5^{2} \mathrm{~g}^{4} \mathrm{c}$.

Source : C. S. Terry 1929 ; K. Geiringer, I 954 .

2. James William Ardenne (1841-1921), $m$. (i) I 886, Emily Lane Harding (1846-1895), first cousin; (ii) 1898 , his $x \cdot 5$ cousin.

\begin{tabular}{|c|c|c|c|c|c|c|c|c|c|c|}
\hline $\mathrm{C}$ & $\mathrm{I} 886$ & 2 & 2 & $\mathrm{I}$ & $\mathrm{I}$ & $\mathrm{I}$ & $\mathrm{I}$ & $\mathrm{O}$ & $\ldots$ & $\ldots$ \\
$\mathrm{I} \cdot 5 \mathrm{C}$ & $\mathrm{I} 898$ & $\mathrm{I}$ & $\mathrm{I}$ & $\mathrm{O}$ & $\ldots$ & $\ldots$ & $\ldots$ & $\ldots$ & $\ldots$ & $\ldots$ \\
\hline
\end{tabular}

Source : Dr R. J. Hetherington, Birmingham.

\section{E. InCOMPLETE}

I. Jens Paulson, of Fana, Bergen, Norway (1870-1953), m. (i) c. I89o, Anna Elizabeth, first cousin ; (ii) $c$. I 9 Io, Martha, Anna's niece, i.e. I. $5 \mathrm{c}$.

\begin{tabular}{|c|c|c|c|c|c|c|c|c|c|c|}
\hline $\mathrm{G}$ & c. I 890 & xо & 6 & 6 & 6 & 24 & $\ldots$ & $\ldots$ & $\ldots$ & $\ldots$ \\
$\mathrm{I} .5 \mathrm{C}$ & c. I910 & Iо & 7 & 7 & 7 & $\mathbf{3}^{\mathrm{x}}$ & $\ldots$ & $\ldots$ & $\ldots$ & $\ldots$ \\
\hline
\end{tabular}

1 One drowned.

Source : Dr John Harper, University of Oxford.

2. Engel,$+ b$. in Hungary; $m$. (i) Siegmund Engel, 1887 , first cousin and also uncle (mother's brother); (ii) Julius Ehrnfeld, Igo2 unrelated.

\begin{tabular}{|c|c|c|c|c|c|c|c|c|c|c|}
\hline $\mathrm{C}$ & $\mathrm{I} 887$ & 4 & 3 & 3 & 3 & 4 & 4 & 3 & $\mathrm{I}$ & $\mathrm{I}+$ \\
$\mathrm{U}$ & $\mathrm{I} 902$ & $\mathrm{x}$ & $\mathrm{0}$ & $\ldots$ & $\ldots$ & $\ldots$ & $\ldots$ & $\ldots$ & $\ldots$ & $\ldots$ \\
\hline
\end{tabular}

1 Defective, mother aged $c .3^{6}$ at his birth.

Source : Dr Eva Bene, London, W.I. 
TABLE I5 (Concluded)

Summary of double test marriages

\begin{tabular}{|c|c|c|c|c|c|c|c|c|c|c|}
\hline & & \multicolumn{2}{|c|}{ Ist $\mathrm{M}$} & \multicolumn{3}{|c|}{ Cousin } & \multicolumn{3}{|c|}{ Unrelated } & \multirow{2}{*}{$\begin{array}{l}\begin{array}{l}\text { Ratio of } \\
\text { increase }\end{array} \\
\text { C:U }\end{array}$} \\
\hline & & $\mathbf{C}$ or $\mathbf{U}$ & Date & c & $\mathrm{gc}$ & ggc & c & gc & ggc & \\
\hline $\begin{array}{l}\text { A. OutBred } \\
\text { I. Sadleir . } \\
\text { 2. Murgatroyd } \\
\text { 3. Henley . } \\
\text { 4. Hugh- } \\
\text { 5. Wadham o }\end{array}$ & $\begin{array}{ll}\cdot & \cdot \\
\cdot & \cdot \\
\cdot & \cdot \\
\cdot & \cdot \\
\cdot & \cdot\end{array}$ & $\begin{array}{l}\mathrm{C} \\
\mathrm{U} \\
\mathrm{C} \\
\mathrm{U} \\
\mathrm{U}\end{array}$ & $\begin{array}{l}\text { I } 839 \\
\text { I } 842 \\
\text { I } 846 \\
1877 \\
\text { I } 889\end{array}$ & $\begin{array}{l}1 \\
6 \\
6 \\
2 \\
2\end{array}$ & $\begin{array}{c}3 \\
\cdots \\
4 \\
\cdots \\
\cdots\end{array}$ & $\begin{array}{r}3 \\
\cdots \\
2 \\
\cdots \\
\cdots\end{array}$ & $\begin{array}{l}\text { I } \\
4 \\
3 \\
2 \\
2\end{array}$ & $\begin{array}{l}1 \\
6 \\
8 \\
1 \\
4\end{array}$ & $\begin{array}{c}\ldots \\
10 \\
23+ \\
6 \\
6\end{array}$ & \\
\hline Total & . & & & 17 & 7 & 5 & 12 & 20 & 45 & $0.3: 3.7$ \\
\hline $\begin{array}{l}\text { B. INTERMEDIATE } \\
\text { I. Wedgwood } \\
\text { 2. Callender } \\
\text { 3. McLeod }\end{array}$ & $\begin{array}{ll}\cdot & . \\
\cdot & .\end{array}$ & $\begin{array}{l}\mathrm{U} \\
\mathrm{C} \\
\mathrm{G}\end{array}$ & $\begin{array}{c}\text { c. } 1860 \\
1865 \\
1891\end{array}$ & $\begin{array}{l}1 \\
4 \\
2\end{array}$ & $\begin{array}{r}\cdots \\
4\end{array}$ & $\begin{array}{r}\cdots \\
5 \\
8\end{array}$ & $\begin{array}{l}\text { I } \\
5 \\
2\end{array}$ & $\begin{array}{r}2 \\
6 \\
\ldots\end{array}$ & $\begin{array}{c}2 \\
14+ \\
\ldots\end{array}$ & \\
\hline Total & . & & & 7 & 10 & 13 & 8 & 8 & 16 & $I \cdot 9: 2 \cdot 0$ \\
\hline $\begin{array}{l}\text { C. INBRED } \\
\text { (i) Non-Fewish } \\
\text { I. Hamilton } \\
\text { 2. v.d. W. Bake } \\
\text { (ii) Jewish (uncle-r } \\
\text { I. David - } \\
\text { 2. Wittner. }\end{array}$ & $\begin{array}{l}\cdot \\
\cdot \\
\text { iiece) } \\
\cdot \\
\cdot\end{array}$ & $\begin{array}{l}\mathrm{U} \\
\mathbf{G}\end{array}$ & $\begin{array}{l}1811 \\
1877 \\
1862 \\
1872\end{array}$ & $\begin{array}{l}6 \\
2\end{array}$ & $\begin{array}{l}9 \\
6 \\
\\
7 \\
5\end{array}$ & $\begin{array}{l}34 \\
14\end{array}$ & $\begin{array}{l}4 \\
3\end{array}$ & $\begin{array}{l}4 \\
4\end{array}$ & $\begin{array}{r}10 \\
9\end{array}$ & \\
\hline Total & • & & & I5 & 27 & $6 I$ & 12 & I3 & 22 & $3 \cdot 4: I \cdot 8$ \\
\hline Grand total: & $\mathrm{A}, \mathrm{B}, \mathrm{C}$ & & & 39 & 44 & 79 & 32 & $4^{I}$ & 83 & $2 \cdot 0: 2 \cdot 6$ \\
\hline $\begin{array}{l}\text { D. Non-ist Cousi } \\
\text { I. Bach }(2 \mathrm{C}: \mathrm{L} \\
\text { 2. Ardenne (C: }\end{array}$ & J) ${ }_{5} \mathrm{G}$ ) & ${ }_{2}^{2 \mathrm{C}}$ & $\begin{array}{l}1707 \\
\text { I } 886\end{array}$ & $\begin{array}{l}7 \\
2\end{array}$ & $\begin{array}{l}6 \\
\text { I }\end{array}$ & $\begin{array}{l}\cdots \\
\cdots\end{array}$ & $\begin{array}{r}\text { I } 3 \\
\text { I }\end{array}$ & $\begin{array}{r}6 \\
\cdots\end{array}$ & $\begin{array}{l}\text { IO } \\
\ldots\end{array}$ & \\
\hline $\begin{array}{l}\text { E. InComplete } \\
\text { I. Paulson (C: } \\
\text { 2. Engel } q\end{array}$ & $\cdot 5 \mathrm{C})$ & $\begin{array}{l}\mathrm{C} \\
\mathrm{C}\end{array}$ & $\begin{array}{l}1890 \\
1887\end{array}$ & $\begin{array}{r}\text { 10 } \\
4\end{array}$ & $\begin{array}{r}24 \\
4\end{array}$ & $\stackrel{?}{\mathrm{I}+}$ & $\begin{array}{r}10 \\
1\end{array}$ & $\begin{array}{l}3 \mathrm{I} \\
\cdots\end{array}$ & $\begin{array}{c}? \\
\ldots\end{array}$ & \\
\hline
\end{tabular}


There are four special points that need to be considered in attempting to apply this test.

First, the capacity to produce first generation children is not at issue. We must therefore compare the descendants of similar numbers of children, or per child.

Secondly, the number of children are likely to be small and unequal in the two families. In one case of the Engel family (table I5, E 2) I had to exclude the family since the sole child of the second marriage was possibly a mongolian type in which the mother's age was the significant factor. I have accordingly also stated in the summary which of the two marriages was the first.

Thirdly, we must divide our families into classes: those that have had no previous inbreeding or likelihood of it, and those that are derived from small social or religious groups that are known to have inbred. In practice, as we have seen, intermediate conditions where inbreeding is beginning give highly diverse results and must therefore be put in an intermediate class.

If we do not make this distinction the grand total of the progenies shows no significant difference between the effects of in- and outbreeding. When we make the distinction according to the antecedents of the families, however, we find that outbreeding favours the outbreeders and inbreeding favours the inbreeders. Further, these differential effects which are apparent in the numbers of grandchildren are exaggerated in the numbers of the great-grandchildren. They are proportionately exaggerated in the extreme example of outbred class A. This effect again suggests, as in table $2 \mathrm{~A}$, assortative mating in respect of fertility.

Apart from the Engel family, the non-first cousin and incomplete progenies in table $\mathrm{I}_{5} \mathrm{D}$ and $\mathrm{E}$, all seem to be from outbred stocks. But since, as tests, they are less significant, detailed enquiries on antecedents have not been made. The Bach family, however, is known to have had no previous cousin marriage. The extinction of the second cousin marriage line and the continuance of the outbred line is historically the most notable case of its kind.

\section{INERTIA AND INNOVATION}

On my interpretation it now seems that human stocks can maintain not only their greatest uniformity but also their highest fertility with regular cousin marriage. Indeed, the change to inbreeding provides the best means of selecting for high fertility. But the introduction of inbreeding in an outbred stock leads to loss of uniformity, viability, fertility, and total reproductive potential. This last effect often extinguishes a line in the second generation, or, owing to assortative mating, in the third or fourth generation, after a cousin marriage.

The method of dividing the population into inbred and outbred stocks and the further method of using parallel and double test 
marriages has indicated a converse principle. This is the principle that outbreeding in an inbred stock, as compared with continued inbreeding, may likewise have a depressing effect on fertility. This inference should be tested with selected results recorded like mine over several generations. The most obvious fields are race crosses (such as Jewish-Christian crosses) and class crosses (such as the morganatic marriages of Royal families.

Following both types of change in the breeding system we may expect what we find in the first, namely that recombination gives lack of uniformity so that, following depression, a few recombinants will establish lines with increased reproductive potential.

These conclusions conform with certain observations reached on very different grounds. For example, considering heterosis in Drosophila, Dobzhansky (I950) concludes that inversion heterozygotes derived from crosses between races may fail to show the advantage that appears in such heterozygotes within a race. Vetukhiv (I954) has inferred an "integration" of the genotype from similar observations. On the other hand, in plants, a change in the breeding system, a shift to inbreeding, has been shown to lead to specific responses. In Campanula and Enothera, following heavy selective elimination, it can change the direction of evolution so as to favour the establishment of altogether new genetic systems such as permanent hybridity (Darlington, I956a, table 27).

These different kinds of reaction have been taken to imply an "inertia" in all genetic systems (Darlington and Mather, I949; Mather, I955). The present observations seem to bear out such an assumption, and it deserves to be fully explored in man as elsewhere. At the same time, however, other principles seem to be disclosed by the present treatment.

The cost of overcoming inertia, the loss of reproductive potential in the generations following a change of breeding system, usually extinguish all but the more fertile lines. But experience shows that it is by just this kind of change that the great innovations in evolution come about. The most successful breeders of cultivated plants have obtained their success, as I have shown in some detail (I956b) by changing the breeding system. The same is true of animal breeding, although here the inbreeding side is better known than the hybridisation, being more recent. So also it must be with man.* Out of the homogeneous, conventional, mediocre, well-adapted mass, recombination will bring new unbalanced types, usually defective, and eccentric, but also sometimes original, usually infertile but sometimes fertile and occasionally creative in both mind and body.

The loss of reproductive potential means the production of very large numbers of unsuccessful types accompanied by very small

* The effects of irradiation may be used as a less satisfactory substitute for a change of the breeding system. The analogy with loss of reproductive potential, rare advantageous effects and dependence on recombination is obvious ( $c f$. Bruce Wallace, 1957). 
numbers of successful types. These types are distinguished mostly not by specific genes but by specific combinations or systems of genes, chiefly of the order of polygenes but no doubt at all levels of gene evolution; usually fragile but sometimes persisting. The process which differentiates between the successful and the unsuccessful types is one of natural selection. The selective advantages concerned are preposterously high, if indeed one can speak of such relations where simple alternatives no longer exist. In this selection the observable character-differentials of classical genetics (or eugenics) are swept along by the overpowering force of the unobservable viability and fertility differentials. The analytical materials and their selective values are trivial in comparison with the rapidly evolving integral effects.

One limitation of these integral or combination effects needs to be noted at this point. They are of value, sometimes only in individuals, sometimes only in small breeding groups; very rarely perhaps are they of value when indefinitely extended. The reason for this is plain. It is that their selection is not bound to concern the individual's relation with his environment. It is bound to concern an integration of the genotype, which is an internal matter: it is, like what we call "personality", an internal integration. The opportunity for external re-adaptation is, however, likely to be taken at the time when the internal re-integration is taking place, since changes in the breeding system in plants and animals and also in man usually arise together with-or even as a result of - changes in the external situation.

In this work of re-integration following a change of the breeding system, assortative mating is shown to be important by our enormous divergences in fertility in the second and third generations. It is therefore worth while recalling the origins of this idea.

Pearson and Lee (1903) having found a possible correlation between husband and wife in height of $0 \cdot 28$, Pearson (anonymously) makes certain novel remarks about sexual selection and about preferential and assortative mating. He points out that assortative mating with positive correlation between mates (which he calls homogamy) as opposed to random mating should have a contrast of effect almost as important as that arising from self- as opposed to cross-fertilisation in plants. He adds that assortative mating, however: (i) may have any degree of intensity; (ii) may be confined to special characteristics; (iii) need have none of the "harmful effects" of inbreeding. Even today, however, we still do not know how far assortative mating in man may not imply inbreeding in respect of particular genes or gene combinations or segments of chromosome.

This question is already raised in my attempt to relate cousin marriage to group inbreeding. It will, I believe, become important at a later stage in the study of breeding systems in man. 


\section{THE ORIGIN OF REGULATED OUTBREEDING}

In sexually differentiated organisms, both sessile and mobile, both plants and animals, self-fertilisation is excluded, and this is the whole means by which inbreeding is directly limited. To this rule man is the sole exception. The rule and its breaking are therefore of vital importance for his evolution. He has adopted conventions which discourage or prevent sib-mating and even all mating within a wide range of kindred. All races of men that have survived today share these conventions. Their results are closely parallel to the similar systems arising in hermaphrodite plants (Darlington, 1943b). Both have to depend on the recognition of kinship. But whereas the recognition of kinship in a plant depends on its genetics, physiology and biochemistry, in man it depends on the special intellectual and cultural apparatus which he has recently evolved. How does it work?

This question has been asked more and more often since MacLennan first used the term exogamy in 1865 . Many answers have been given. A few of these answers have rested on biological grounds. During his life, Darwin's explanation (1876) that outbreeding, as opposed to inbreeding, enhanced vigour or avoided debility in the offspring, or even the posterity, generally carried weight. But this belief, even at the time, could be seen to be mistaken and my evidence helps to show what the mistake was and how it arose. Fertility over several generations is a stricter test than viability in one generation. And fertility is as compatible with close inbreeding in man as it is in other animals or plants.

Most answers, however, have rested on no biological grounds at all. They have rested on arguments from purely human properties of custom, religion or fancy. The arguments attempted to explain what their authors did not understand, the biological property of outbreeding, in terms of what nobody understands, the local origins of human superstition. Explanations by Herbert Spencer, Frazer, Freud and others, therefore, run in smaller and smaller circles. These have been well described by Lord Raglan but even he has added his own magical formula to the series.

The most recent is of larger scope and deserves special mention. It is that of Lévi-Strauss (1949). This distinguished anthropologist states his conclusion at the beginning in the following words:

"La prohibition de l'inceste ... constitue la démarche fondamentale grâce a laquelle, par laquelle, mais surtout en laquelle, s'accomplit le passage de la Nature a la Culture." (p. 30).

Thus Lévi-Strauss by stating the fact three times (a fact which no one disputes) seems to persuade himself that he has explained the fact. This is just what he avoids doing. He has to avoid explaining it because he is unwilling to make any genetic assumption. 
Now we know, however, that the long-term properties of genetic systems are themselves genetically controlled. We know that in all organisms they are subject to selection and evolution. And we knowthis arises from the last thirty years' work - that wherever the longterm selective advantage can be traced it is the same: it is the securing of recombination and hence of adaptability in the population, and the securing of this sequence of advantages by outbreeding (Darlington, I958a).

Outbreeding in all sexual organisms is only secondarily important for its immediate individual effect of avoiding homozygosity. Primarily it is important for its enduring population effect of exploiting heterozygosity. That is for combining lack of variation in a breeding group with the capacity to release variation when the breeding group either contracts or expands: which it does whenever conditions change; whenever, that is, they become unfavourable.

Enforced outbreeding therefore at once gives any population which knows how to adopt it an advantage over those which do not, the advantage of rapid adaptability. A change to inbreeding in such a population at once splits it into dissimilar groups, each homogeneous but with a homogeneity from which there is no return.

In these terms we can now see what happened at a certain stage in the evolution of man. As families stayed together longer, and as an intelligent recognition of kindred developed with discrimination, there would also develop that assortative mating which in man is peculiarly an intellectual gift. Groups would become more and more inbred, unadaptable and fissiparous. Large, homogeneous, co-operative groups could come into existence only when the gift of recognition of kindred was exploited to enforce the avoidance of mating with kindred. The recognition of kindred would therefore lead to a breeding crisis. The groups that survived would be those which had used their new gift to develop a system of outbreeding. The behaviour of primitive peoples throughout the world shows that they are all descended from such groups.

Regulated outbreeding not only limits inbreeding; it also limits or even abolishes assortative mating. For the regulation is often elaborate enough to leave no choice of mates. In both of these ways it tends to maintain a phenotypic homogeneity in the group. This homogeneity makes possible the cohesion without specialisation, the conformity with tradition and continuity, characteristic of tribal life. When the breeding system changes, this character breaks down and we have "detribalisation". The breeding system is thus necessary in maintaining the adaptation of the primitive community not only externally to its environment, but also internally to its own parts as reflected in reproductive and cultural stability.

In selecting a genetic propensity for outbreeding in man nature therefore showed, not only a long-term preference for recombination, which we know to be universal, but also, as Tylor implied already in 
I889, a short-term preference for social co-operation and initiative, which is peculiar to man himself.

If we imagine the contrary state, and indeed the pre-existing state of a society of baboons with no conventional restriction to mating at all, we can see what would have happened to it with man's developing intelligence. The tribe would be continually subject to splitting up by brother-sister mating into groups of irregular size and differing character just as happens in our own society to a less degree with inbreeding. Such irregularity would disintegrate tribal communities at the moment when intellectual processes began to affect mating habits.

The clumsiness, over-elaboration and occasional inefficiency or irrelevance of the rules which are connected with man's avoidance of inbreeding are of minor interest to the geneticist. He can see where they lose their aim. The complex of rationalisations and myths by which man has explained, justified and reinforced these rules, on the other hand, are characteristic of all his behaviour. They are of major interest to the anthropologist. He regards them as the genuine foundation of man's behaviour. But I am arguing that these ideas are secondary and derived. Derived from what? Derived always from instincts, from genetically determined systems of behaviour, selected for their long-term adaptive advantage and leading to an aversion for breeding between close kindred, an aversion for what at this stage we may call incest.

The instincts of a majority would establish social codes and mating taboos much on the lines proposed by Darwin in the Descent of Man. It would then be difficult and dangerous for diverging individuals to break the rules. Royal families could most easily do so, as they have done in varying degrees. The loss of the instinctive aversion to inbreeding also, we may note, runs in families. Does it do so for genetic as well as for merely imitative reasons? Consider the incest of Byron the poet, and of his father, each with a sister. The grandparents of all four were first cousins, and all members of the family who could marry first cousins did so. Is there a genetic component in this sequence? I believe so.

The third stage in the development of breeding rules is that where instincts pass into conventions, conventions pass into law, and it is worth noting that incest has been decreed a crime at many times in history. It was not, however, until i 908 that this stage in the organisation of the breeding system was reached in England, and it is a stage which may never be reached in other European countries. The position of homosexuality is analogous. Similar selective advantages must obviously operate against homosexuality and similarly give rise to moral precepts and legal sanctions. In both cases the precepts and sanctions have an instinctive basis; they are irrational and may be misguided.

The study of breeding behaviour and its effects in man on these lines helps us to disembarrass ourselves of a number of prejudices in 
deciding on our future behaviour. It may help us to interpret the relations of instinct, reason and superstition where they are most entangled. The tribal breeding units, between whose instincts and hence customs selective processes originally distinguished, are now largely disintegrating. And in civilised societies the instincts are reduced to conventions supported by fallacious rationalisations. The long-term selective forces favouring adaptability in tribal societies are now superseded. All that is left is the evidence of what we may call instinctive residues, religious beliefs, and the secondary selective forces affecting individual survival. This evolutionary flotsam still gives stability to breeding systems. It also confuses the observer who confines his attention to man.

The parallel gifts for regulated outbreeding and for assortative mating, or outbreeding with discrimination, are, as I have suggested ( $195^{8 b}$ ), the two inventions on which the evolution of human societies is based. They have been in a sense twin foundations; but rather more they have been connected and balanced foundations of his breeding system. They have made possible, first, the tribal society and, secondly, in the last ten thousand years, the class-differentiated society, the unprecedentedly rapid evolution of which we call civilisation. It is on their study that the future will also depend.

\section{SUMMARY}

I. In advanced societies taken as a whole a specific class of breeding (such as cousin marriage) shows no very pronounced departure from the average result in regard to any particular attribute of the progeny.

2. But when families are classified by their breeding system over several previous generations, and when all attributes are taken together as measured by the reproductive potential over several subsequent generations, decisive differences are found.

3. Inbreeders suffer by outbreeding and outbreeders by inbreeding. This is true on the average of each of the successive reproductive tests in the progeny: viability after birth, marriage frequency and numbers of the second generation.

4. These average effects are compatible with greater heterogeneity and the production of new strains, new recombinations, enhanced in fertility and no doubt often in other respects.

5. Assortative mating in respect of fertility, otherwise difficult to show, is to be inferred from the maintenance or exaggeration of these differences in successive generations.

6. The value of regulated outbreeding for primitive man was not in its avoiding homozygosity but in its providing homogeneity in an enlarged breeding group together with an immediate capacity for variation when the group changed either by contraction or expansion.

7. The origin of the regulation of outbreeding, it is suggested, was in the development of appropriate instincts on the lines proposed by 
Darwin. This development would be favoured by their enormous long-range selective advantage on the principles of evolution in genetic systems as established in animals and plants generally.

Acknowledgments.- I am indebted to the named families and the named individuals from all parts of the world who have kindly and often with enormous labour provided me with the information which I have here collected. Prof. F. A. Pottle of Yale University and Mrs Enid Grant of Edinburgh kindly helped me with the Boswell family and Mr K. B. McFarlane of Magdalen Gollege with the Byron family. I am particularly indebted to Mr Michael Eden, Mr Richard Kindersley and $\mathrm{Mr}$ Raymond Lucas for pointing out to me, on their own initiative, new ways of handling the data. I also want to thank the Observer newspaper of London and Messrs Sandoz of Basel for making known my enquiry to a larger public.

\section{REFERENCES}

ALSTRÖM, C. H. 1958. First-cousin marriages in Sweden, 1750-1844. Acta Gen. Stat. Med., 8, 3-4.

BEMISS, s. M. 1858. Report on influence of marriages of consanguinity upon offspring. Trans. Am. Med. Assn., 11, 319-425.

BLoomfield, R. 1956. Uncommon People: a Study of England's Elite. London.

CAMPBELL, H. 1958. Infertility : its incidence and hope of cure. Brit. Med. Fourn., 429-433.

DARLINGTON, C. D. I943a. Race, class and mating in the evolution of man. Nature, 152, 315-319.

DARLINGTON, C. D. I $943 b$. The place of the Australian aboriginal in the evolution of society (Introduction). Ann. Eugen., 12, 44-45.

DaRLington, C. D. I 955 . Heterosis from the point of view of the chromosomes. Proc. Roy. Soc. B, 145, 350-364.

DARLington, G. D. I956a. Natural populations and the breakdown of classical genetics. Proc. Roy. Soc. B, $145,350-364$.

DARLington, C. D. I956b. Chromosome Botany. Allen and Unwin, London.

Darlington, C. D. 1957. Messages and movements in the cell. Conf. on Chromosomes, Wageningen. Willink, Zwolle.

Darlington, c. D. I958a. Evolution of Genetic Systems. 2nd ed. Oliver and Boyd, Edinburgh.

DARLINGTON, C. D. I958b. Control of evolution in man. Nature, 182,14 -17.

DARLINGton, C. D. I958c. Cousin marriages. Triangle, 3, 277-280.

DARLington, C. D., AND MATHER, K. 1949. The Elements of Genetics. Allen and Unwin, London.

Darlington, c. D., And mather, K. 1950. Genes, Plants and People: Essays in Genetics. Allen and Unwin, London.

Darwin, G. I87I. The Descent of Man. London.

DARWIn, c. 1876. The Effects of Cross and Self Fertilisation in the Vegetable Kingdom. London.

DARWIN, H. G. (SIR GEORGE). 1875. Marriages between first cousins in England and their effect. Fortnightly Rev., 24, 22-41.

DobzhansKy, тH. 1950. Genetics of natural populations. XIX. Origin of heterosis through natural selection in populations of Drosophila pseudoobscura. Genetics, 35, 288-302.

DOBZHANSKY, TH., AND PAVLOVSKY, o. 1958. Interracial hybridization and breakdown of coadapted gene complexes in Drosophila paulistorum and Drosophila willistoni. P.N.A.S., 44, No. 6, 622-629.

eaton, J. W., AND MAYER, A. J. 1954. Man's capacity to reproduce. Hum. Biol. (Baltimore), 25 (3). 
FISHER, R. A. I930. The Genetical Theory of Natural Selection. Oxford.

FISHER, R. A. I949. The Theory of Inbreeding. Oliver and Boyd, Edinburgh.

FRACCARO, M. I958. Incidence of consanguineous marriages in Sweden. Hereditas, $44,65-74$.

GALTON, F. I869. Hereditary Genius. London.

GEIRINGER, K. I954. The Bach Family. Allen and Unwin, London.

GOLDSCHMIDT, E., AND RONEN, A. I956. The rate of consanguinity in the communities of Israel. Bull. Res. Council, Israel, ${ }_{5}$ B. 31 7-3 18.

HUTH, A. H. 1875. The Marriages of Near Kin considered in respect to the Lawes of Nations, the Results of Experience and the Teachings of Biology. London.

HUTH, A. H. I879. Index to books and papers on marriage between near kin. Rep. Ist Ann. Meeting Index Soc., 25-44.

Kilpatrick, s. J., MATHERs, J. D., AND STEvenson, A. c. 1955. The importance of population fertility and consanguinity data being available in medicosocial studies. Ulster Med. Four., 24, I I3-1 22.

LÉvi-STrauss, C. 1949. Les Structures Elementaires de la Parenté. P. Univ. France, Paris.

Mather, K. I955. The genetic basis of heterosis. Proc. Roy. Soc. B, 144, I43-1 50.

MONCRIEFFe, I., AND POTTINGER, D. I956. Blood Royal. London.

MORTON, N. E., CROW, J. F., AND MULLER, H. J. 1956. An estimate of the mutational damage in man from data on consanguineous marriages. P.N.A.S., $4^{2}$, No. I I, $855 \cdot 863$.

NEEL, J. V., KODANI, M., BREWER, R., AND ANDERSON, R. C. I949. The incidence of consanguineous matings in Japan. Am. 7. Hum. Genet., 1, I56-I57.

PEARSON, K. 1902. Assortative mating in man. Biometrika, 2, 481-498.

PEARson, K., AND LeE, A. I899. On the inheritance of fertility in mankind. Phil. Trans. R.S. (A), rg2, 279-29o.

PEARSON, K., AND LEE, A. I 903 . On the laws of inheritance in man. I. Biometrika, $2,357-462$.

RAGLAN, LoRD. 1933. Focasta's Crime: an Anthropological Study. Methuen, London. SCHULL, w. J. I958. Empirical risks in consanguineous marriages: sex ratio, malformation and viability. Am. F. Hum. Genet., ro, 294-343.

SLATIS, H. м. et al. 1958. Consanguineous marriages in the Chicago region. Am. 7. Hum. Gen., ro, 446-464.

stevenson, A. C. I956. Applications of epidemiological methods to the study of congenital malformations in man. Ulster Med. Four., 25, Io I-I Io.

TERRY, C. S. 1929. The Origin of the Family of Bach Musicians. Oxford.

vetukHiv, м. I954. Integration of the genotype in local populations of three species of Drosophila. Evolution, 8, 241-25I.

WALLACE, BRUCE. 1957a. The effect of heterozygosity for new mutations on viability in Drosophila: a preliminary report. P.N.A.S., 43, No. 5, 404-407. WALLACE, BRUCE. $1957 b$. Some of the problems accompanying an increase of mutation rates in Mendelian populations. Effect of Radiation on Human Heredity. W.H.O., Geneva.

\section{APPENDIX : ABBREVIATIONS}

$\mathrm{cm} \quad$ first cousin marriage (three pairs of grandparents, one in common)

$\mathrm{cm}$ (d) double $\mathrm{cm}$ (two pairs of grandparents, both in common)

$\mathrm{cm}(\mathrm{r}) \quad$ reciprocal $\mathrm{cm}$, of pairs with same three pairs of grandparents

$\mathrm{cm}$ (par) parallel $\mathrm{cm}$ between pairs of sibs

$\mathrm{cm}(\mathrm{I} \cdot 5)$ first $\mathrm{cm}$ once removed

$\mathrm{cm}(2)$ second $\mathrm{cm}$

$\mathrm{scm}$ successive $\mathrm{cm}$, i.e. involving descendants of a $\mathrm{cm}$ after one or two generations

$\mathrm{dtm}$ double test marriage 


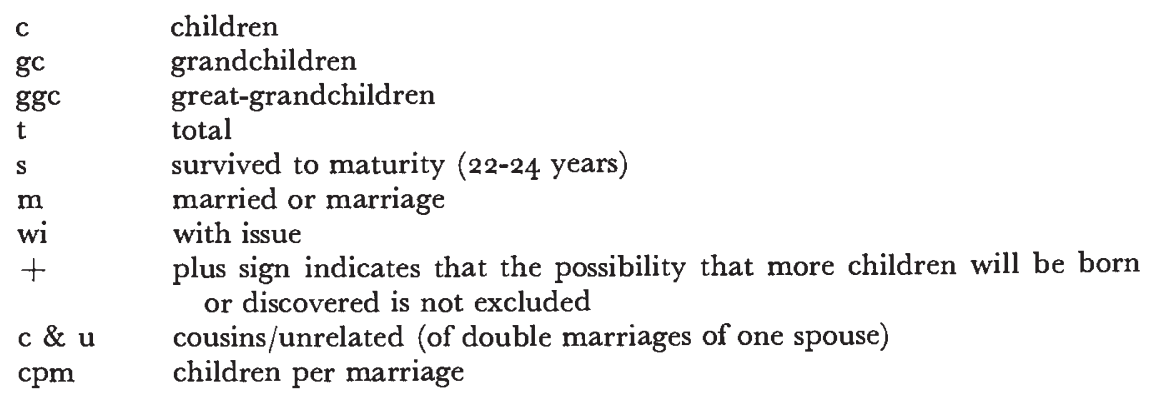

